\title{
تأهيل الإصابة بالفتق الأربى للرياضيين داخل وخارج الوسط المائى بعد التدخل بالمنظار الجراحى داري
}

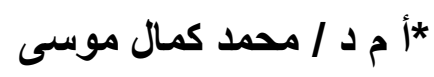

مقدمة البحث ومشكنتها :

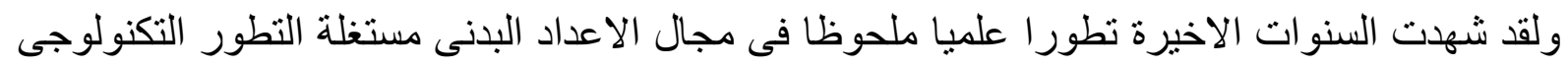

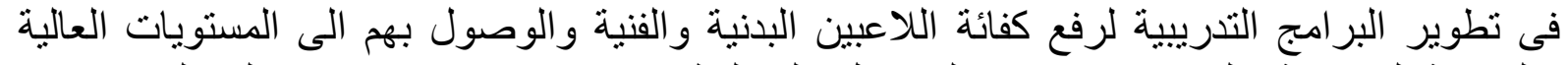
و الفورمة الرياضية والتى بدور ها تحقق الحصول على البطولات لات وإحر از الانتصار ات و الميداليات .

و لا شك ان هدف المدرب هو الوصول باللاعب الى اعلى مستوى ممكن من حيث اللياقةالبدنية والمهارية

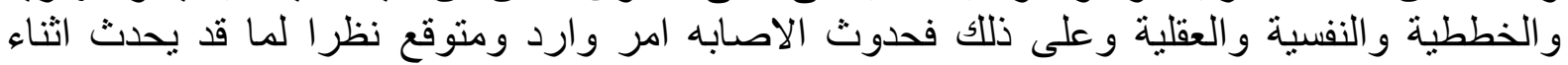

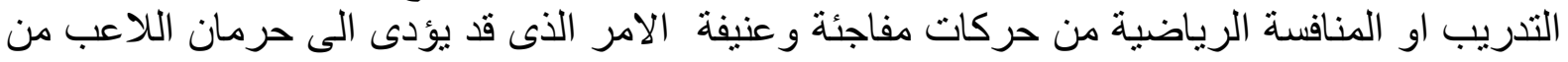

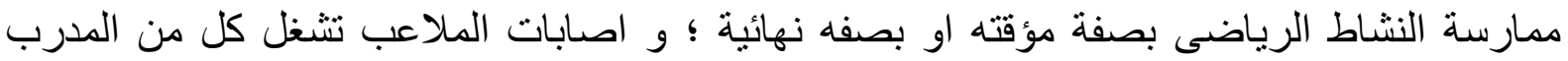

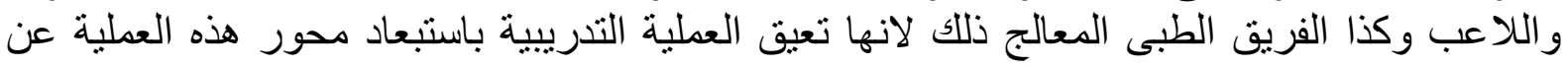

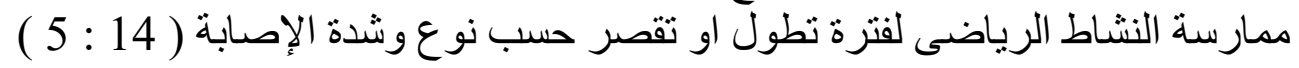

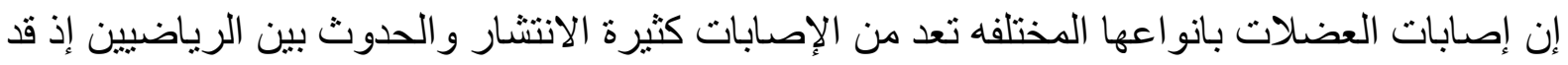

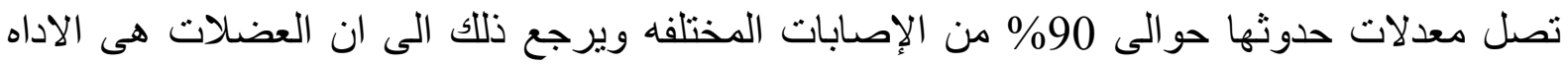

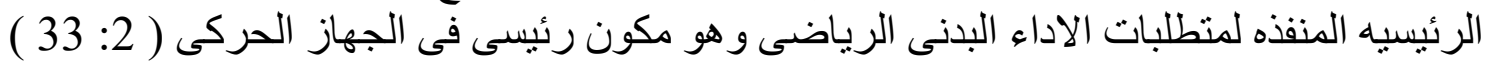

و الرياضه بجميع اشكالها عادة تكون انشطه تنافسيه ورذه الانشطه التى تتسم بالثدة ربما تتسبب فى

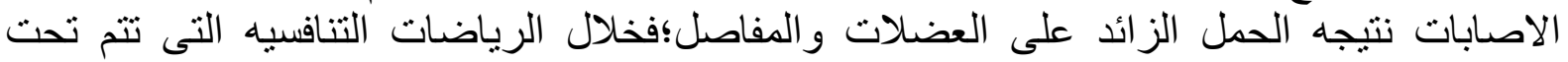

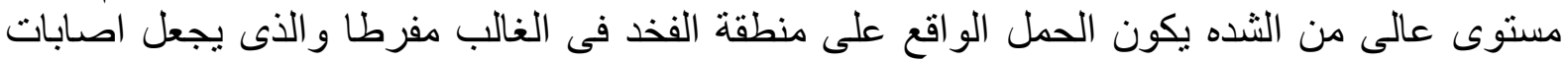

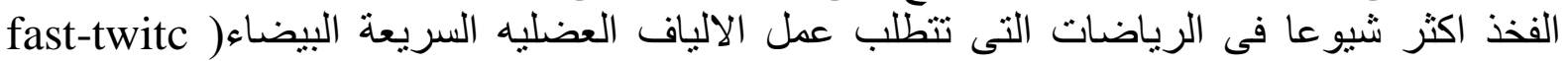

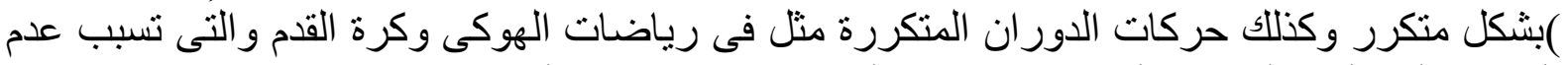
التوازن العضلى و الضعف الذى ينشاء بسبب التوزيع غير منساوى القوة

forces)

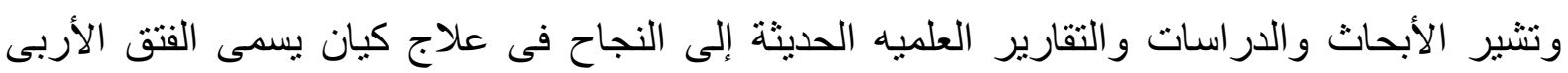

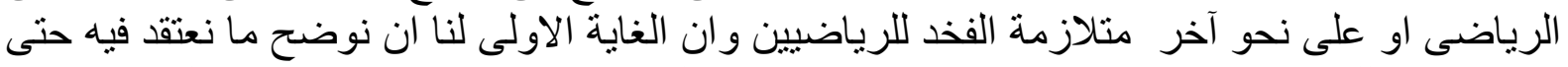

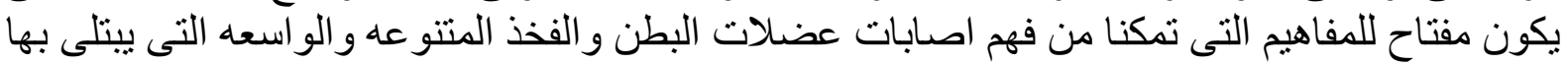

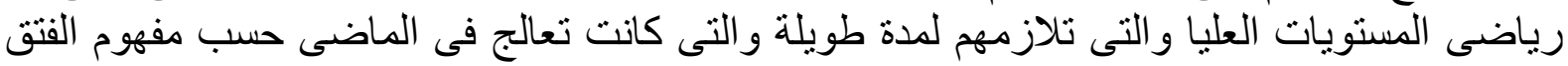

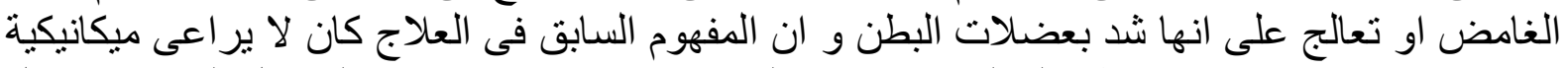

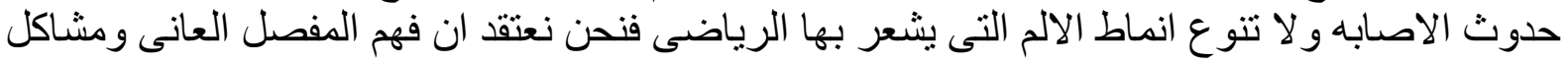

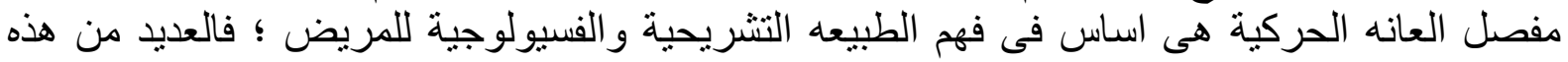

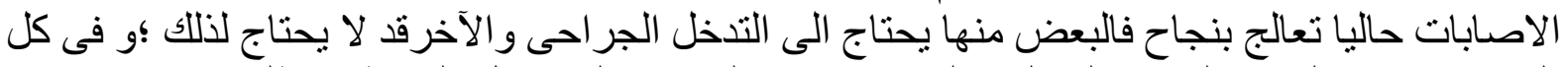

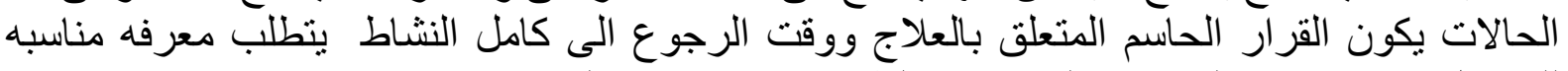

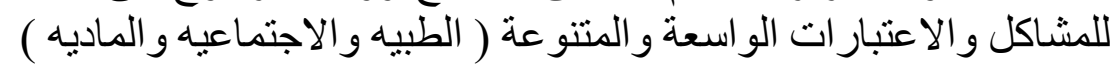

و الفتق الرياضى يوصف بأنه الم غير مبرر بالفخذ وهو نشخيص شائع والبعض يؤمن بانه السبب الاكثر

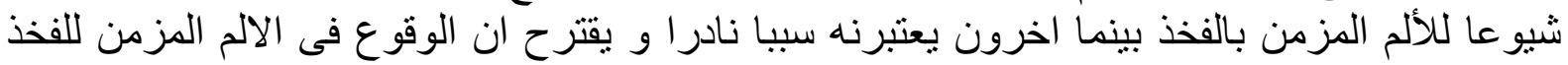

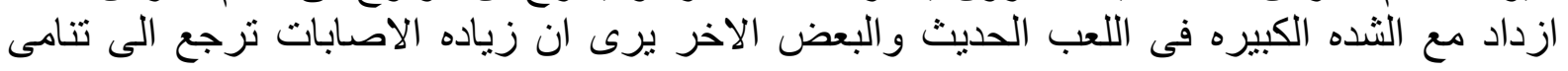


الوعى التدريبى لاى المدربين ؛و ان الفتق الرياضى هو واحد من الموضو عات الاقل فهما والافقر فى (24 الإق

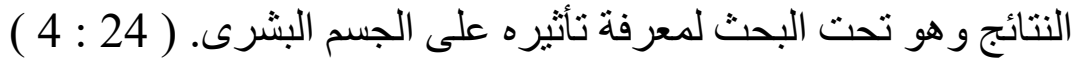

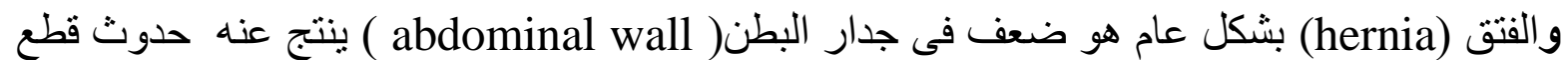

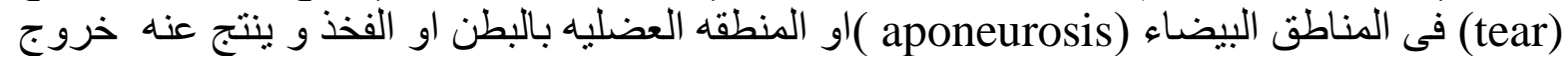

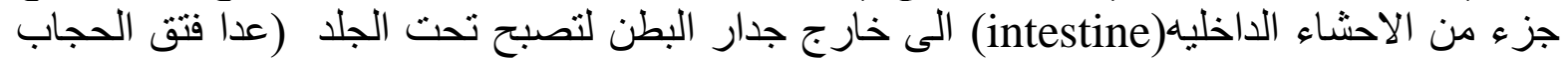

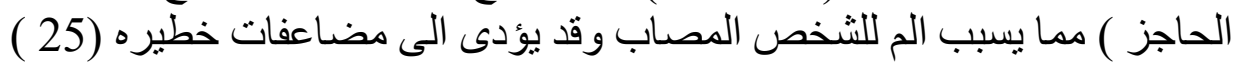

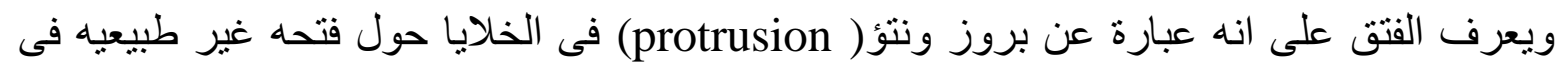

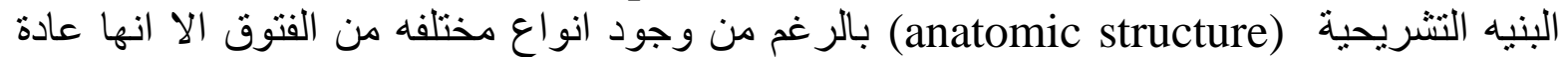

ترتبط بالبطن حو الى( 75\%) من مجموع الفتوق و تحدث فى المنطقه الاربيه (inguinal region.

( $844: 19$ )

و هنالك انواع عديده من الفتوق من المكن ان يصاب بها الرياضى فهناك فتق المنطقه الاربيه

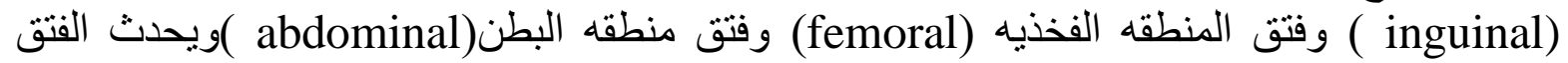
نتيجه التمزق المفاجئ للعضلات او اللفائف (fascia) وقد يزداد اتساع الفتق تدريجيا نتيجه الاستمر ار

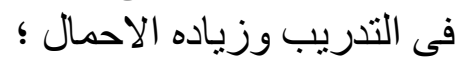

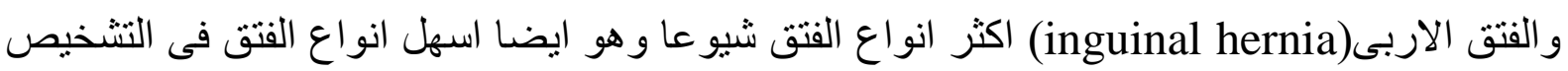

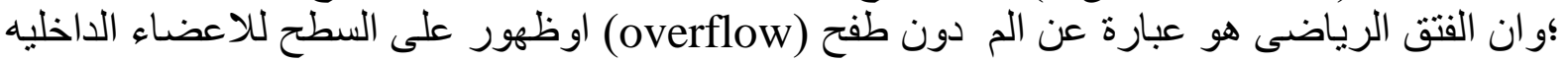

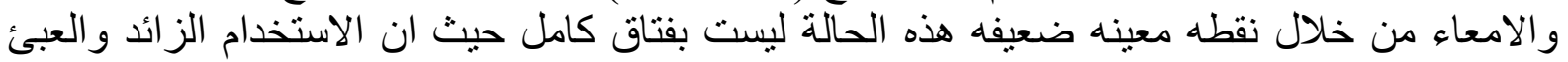

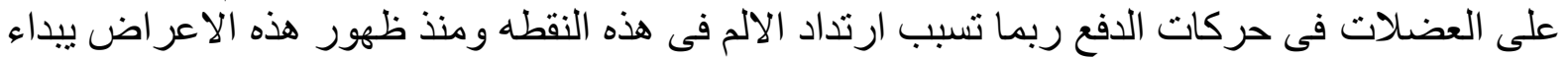

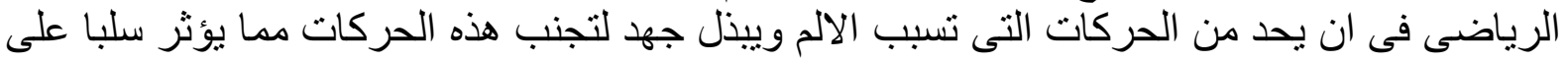

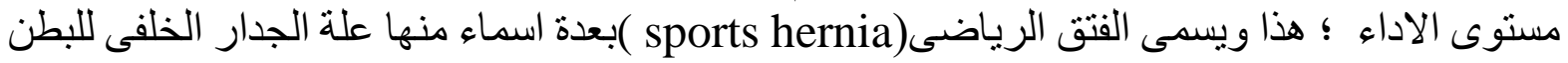
(incipient hernia) ومنتازمة جلمور (posterior abdominal wall deficiency) ومتلازمة الفذذ للرياضيين(Gilmore's groin) انه حاله من الالم تتعلق بالتمرينات التى تتطلب انقباض في عضلاضلات البطن بقوة ويكون الالم و اقع اعلى المنطقه الاربيه (16 : 112 ( 11 )

الأعراضSSymptomsiدأ الاعر اض عادة مع بداية بطيئة من الاحساس بعدم الراحة فى منطقة أسفل

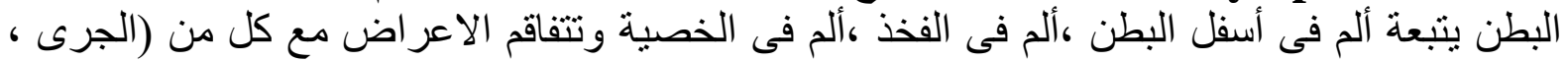

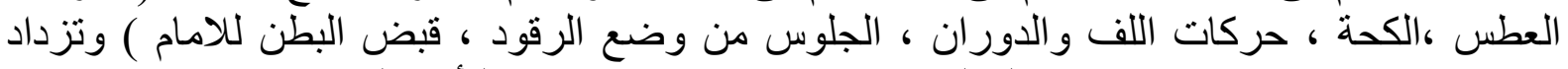

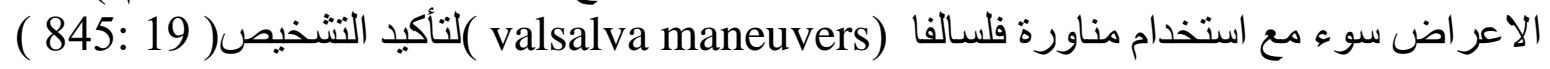

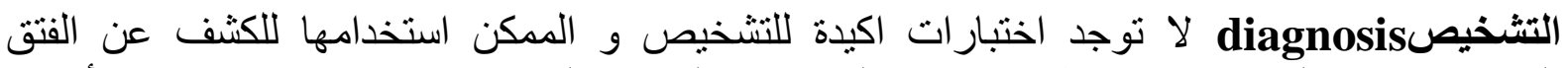

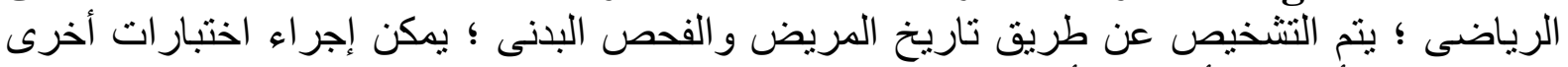

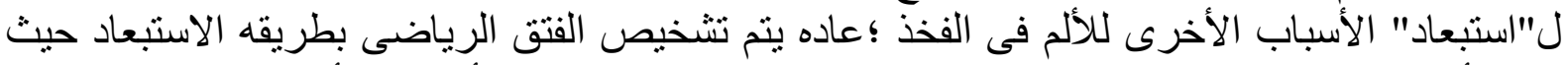

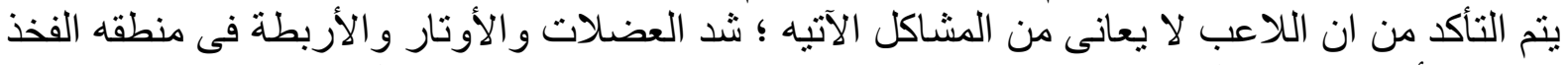

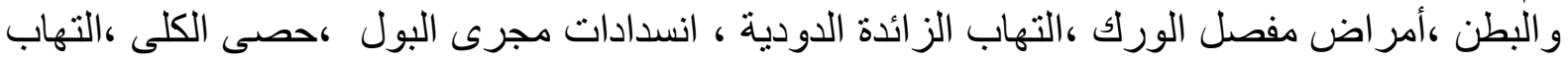

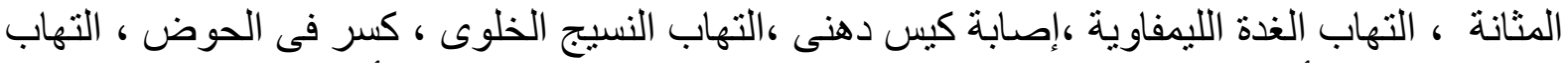

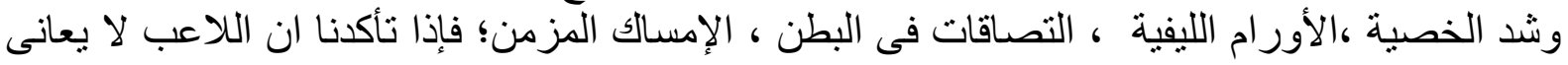

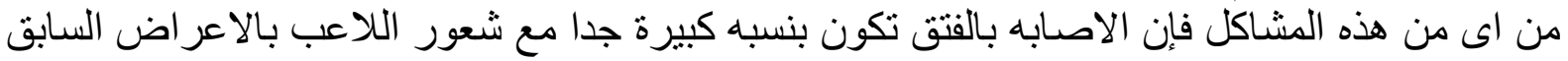

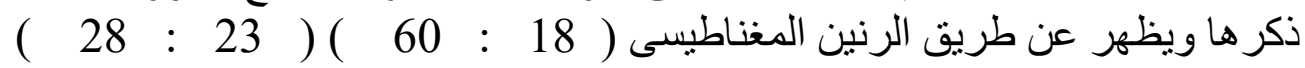


ميكانيكية حدوث الاصابه(mechanism of injury)(ان السبب المرضى لهذه الحاله ليس مفهوم

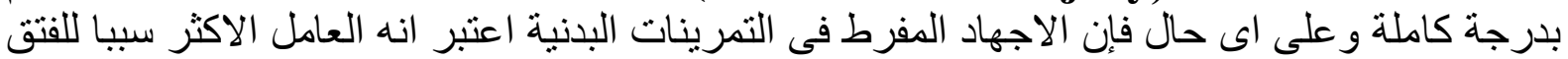

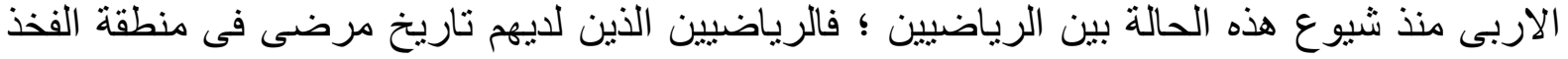

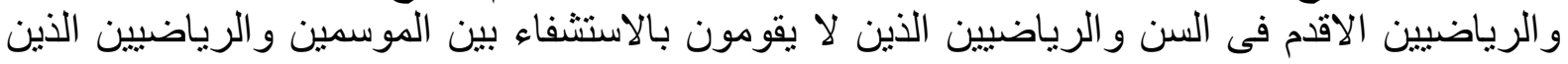

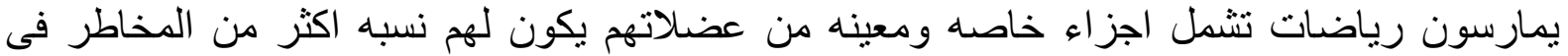

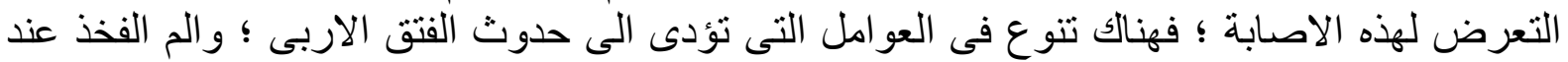

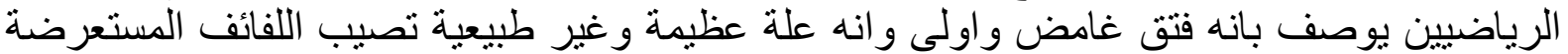

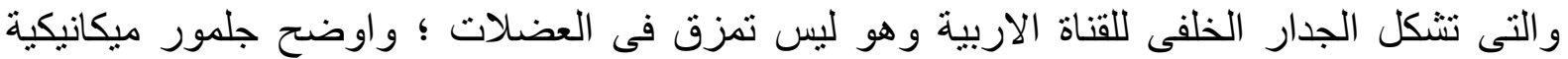

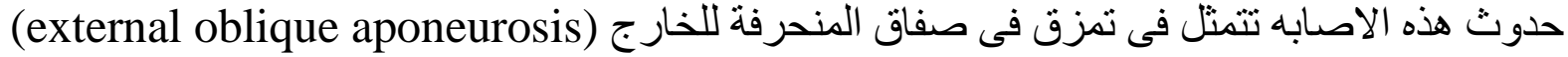

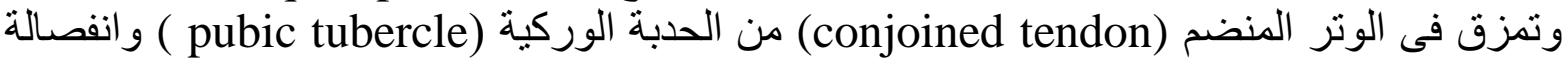

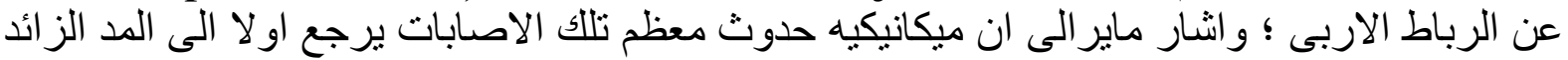
فوفى عضلات البطن و التبعيد الزائد hyperextension

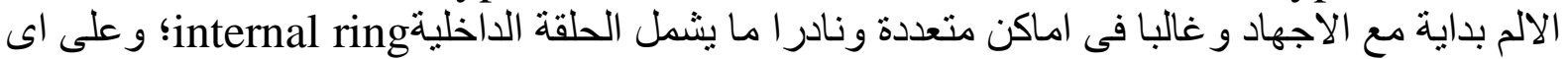

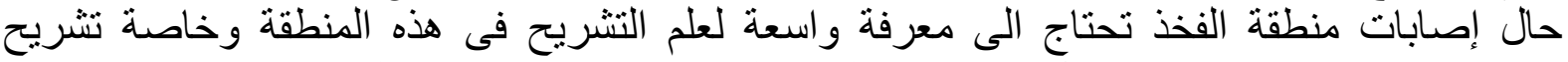

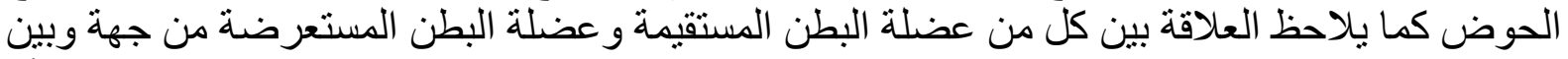

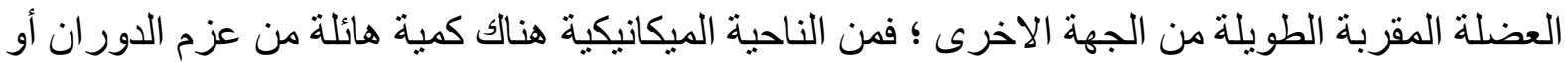

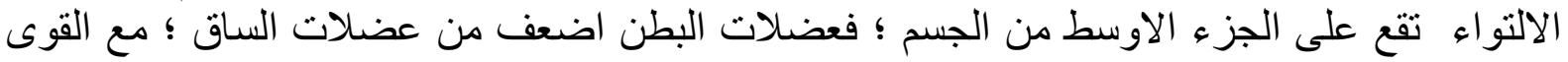

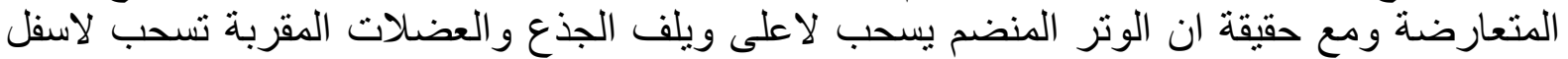

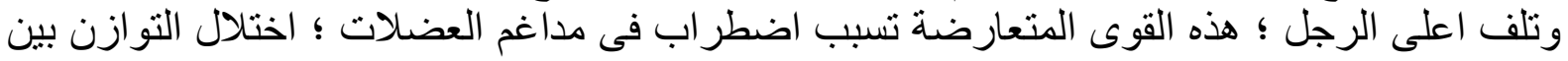

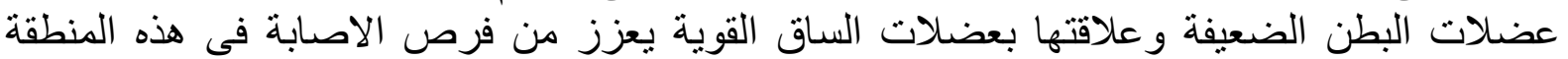

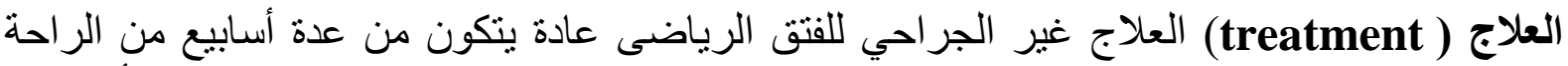

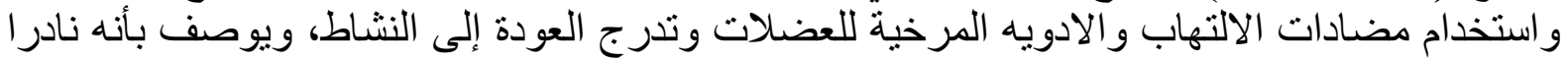

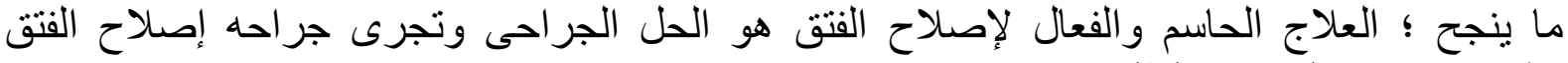

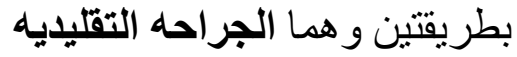
و جراحه اصلاح الفتق الرياضى عن طريق المنظار وذلك من خلال ادخال المنظار الى المنطقه الاربيه

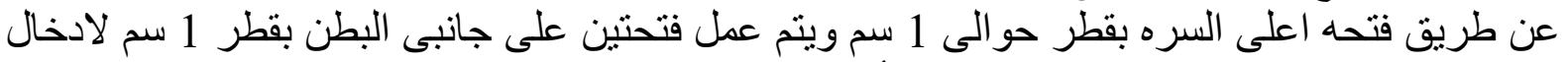

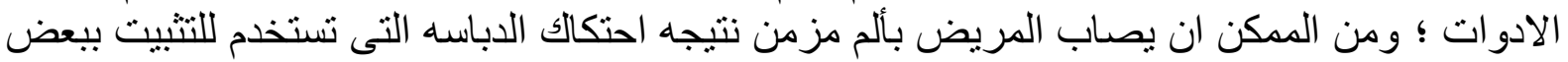

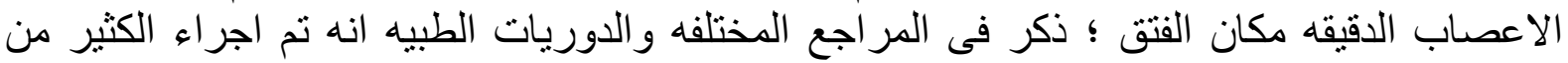

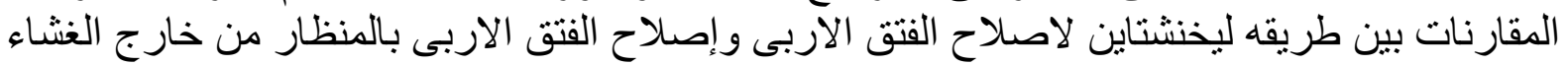

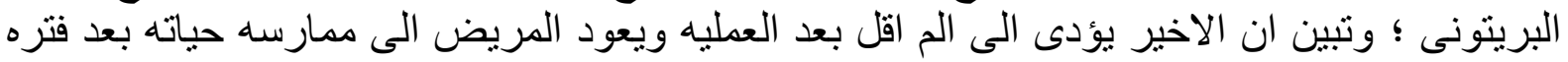

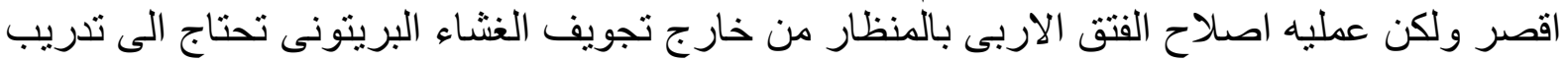

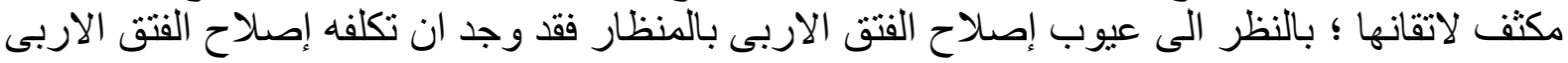

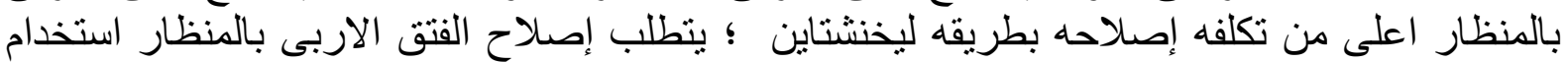

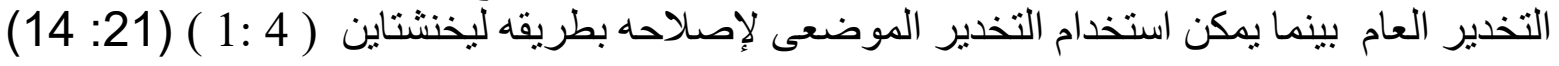

وتكمن المشكلة الحقيقية للبحث فى عدم وجود برنامج تأهيل واضح ومحدد المعالم بيبين الاحتياطات

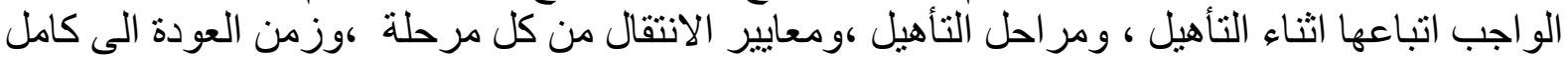

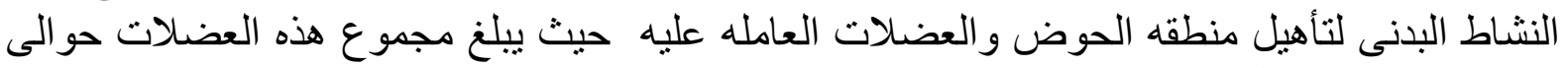

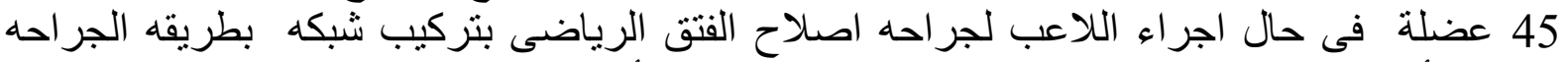

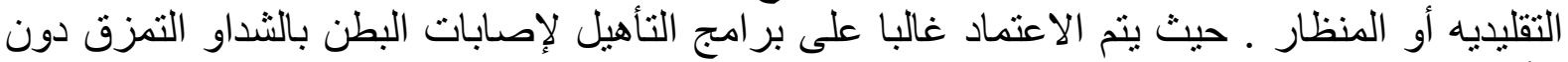

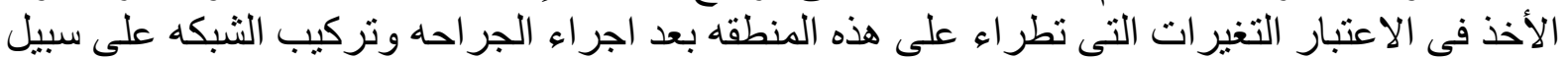




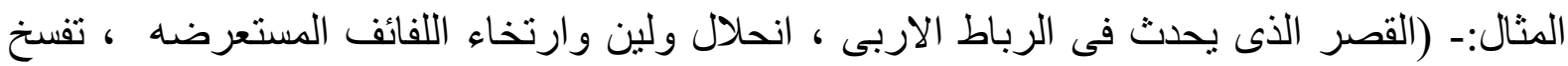

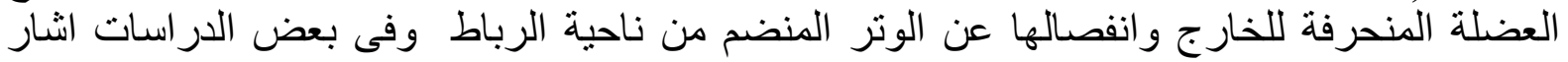

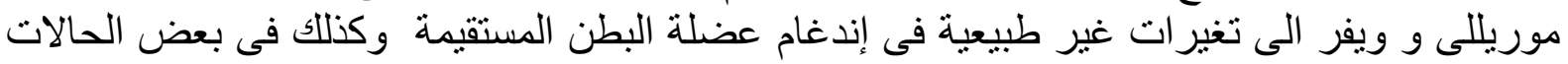

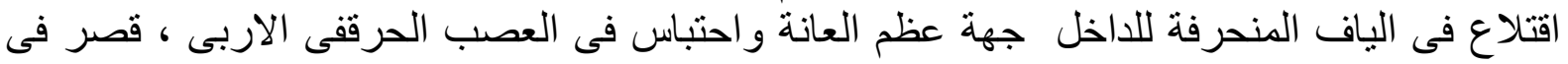

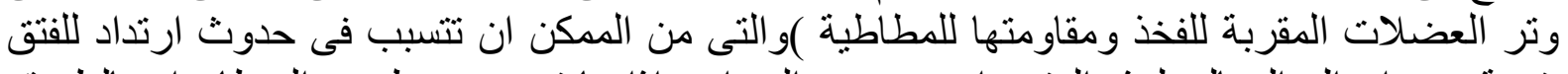

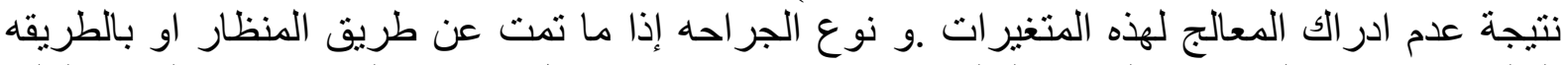

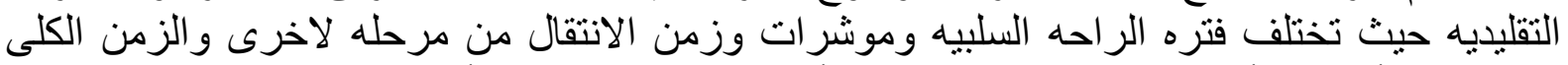

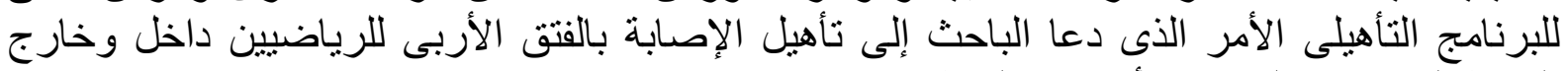

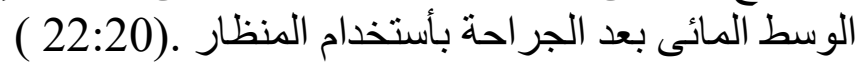

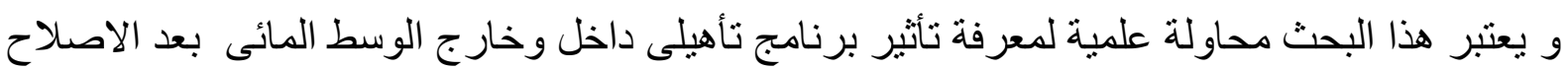

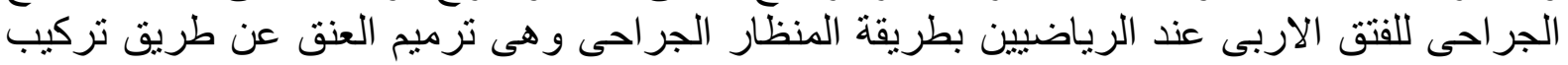

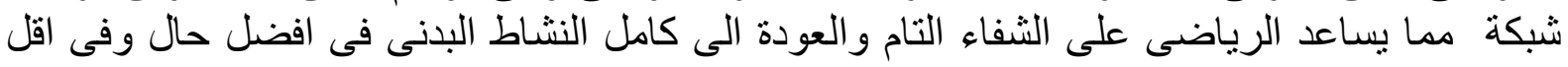
وقت ممكن

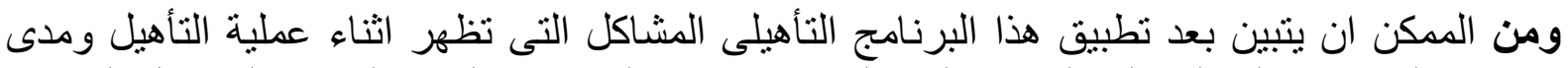

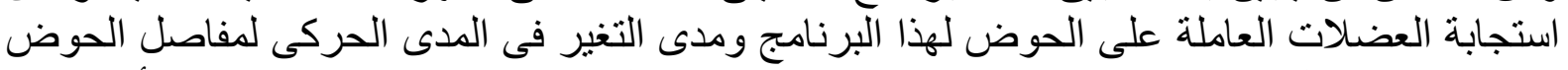

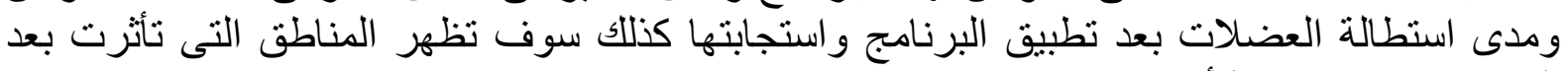
الجر احة ودرجة هذا التأثنير

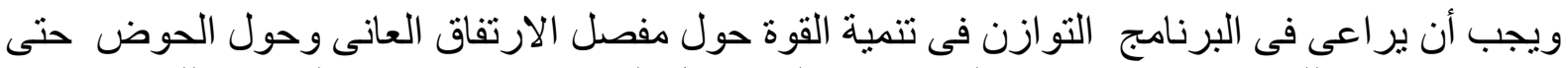

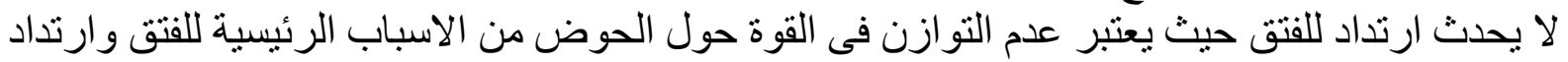

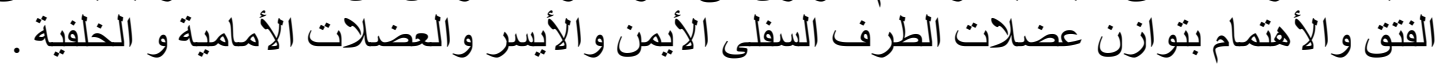

\section{اهداف البحث}

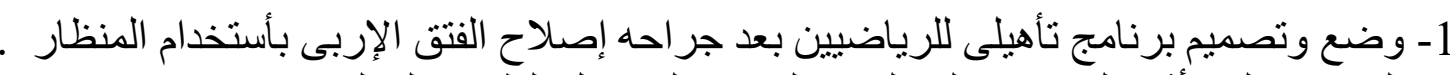

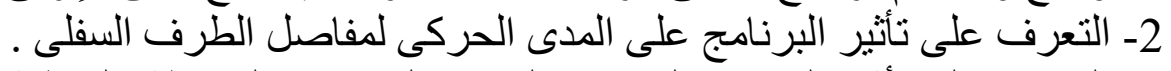

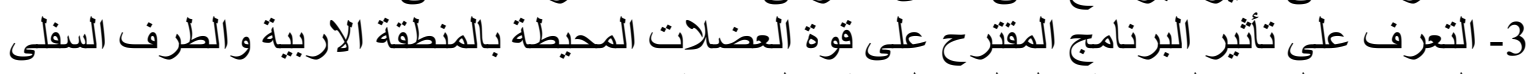

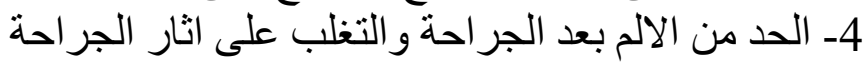

\section{فروض البحث}

1. يعمل البرنامج التأهيلى المقترح على تحسين المدى الحركى فى مفاصل الطرف السفلى

r. . يؤثر البرنامج التأهيلى المقترح إيجابيا على قوة عضلات البطن و العضلات العاملة على مفاصل

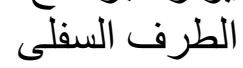
r. يحد البرنامج التأهيلى المقترح من درجه الالم الذى يتعرض له اللاعب بعد الجر احه

منهرج البحث : الدراسة : استخدم الباحث المنهج التجريبى لمجموعة تجريبية واحدة بأستخدام القياسات القبلية

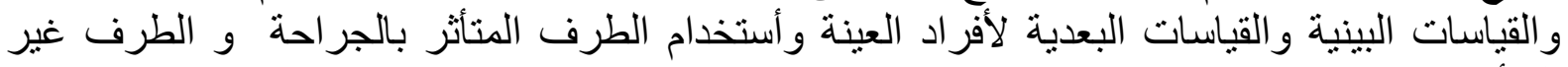

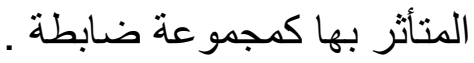




\section{مجالات البحث

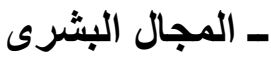

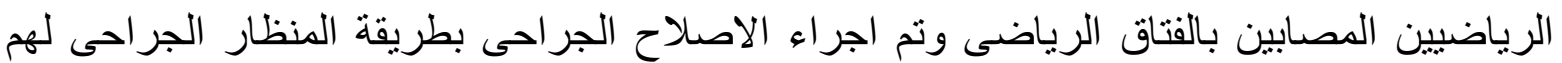

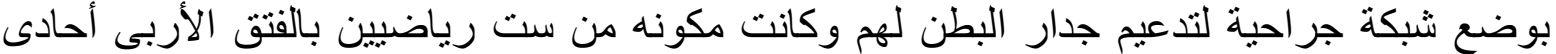

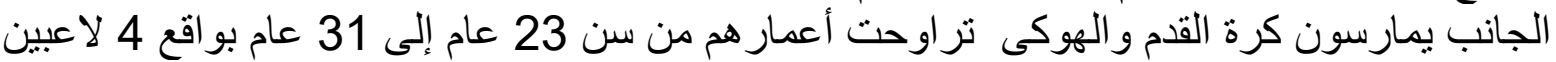
كرة قدم و2 ل الاعبين هوكى .

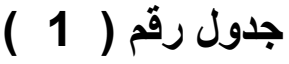

الدلالات الإحصائية الخاصة للمتغيرات الاساسية لعينة البحث ( السن ـ الطول ـ الوزن )

\begin{tabular}{|c|c|c|c|c|c|c|}
\hline معامل الالتواء & الالمعراف & المستوسط & قيمة & قيمة & القياس & المتغير \\
\hline 1.17- & 2.79 & 28.16 & 31 & 23 & عام & السن \\
\hline 0.73 & 5.52 & 175.83 & 185 & 170 & سم & الطول \\
\hline 0.148- & 6.03 & 72.83 & 82 & 63 & كج & الوزن \\
\hline
\end{tabular}

يتضح من الجدول رقم (1 ) أن البيانات الخاصة بعينة البحث فى المتغيرات الاولية الاساسية

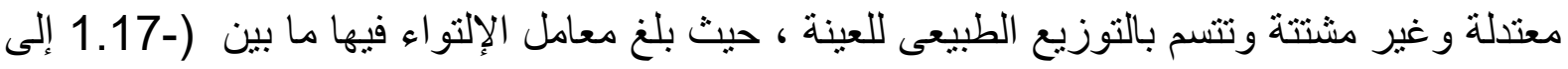
0.73) و هذه تنحصر بين ( د3 ) ، مما يؤكد على التجانس في المتغيرات الاساسية لعينة البحث قبل

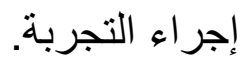

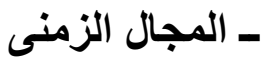
اجريت التجربه الاساسية للبحث فى الفترة من 15 / 12 / 2014 وحتى 2015/11/29

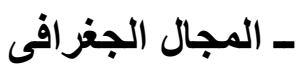

بنادى النصر للقوات المسلحه ومركز ايفليوشن بسموحة حيث تتو افر الامكانات المطلوبه من ادوات ووسائل العلاج الطبيعى وصالة لتنفيذ برنامج التأهيل ( جيم ) وحمام للسباحه 


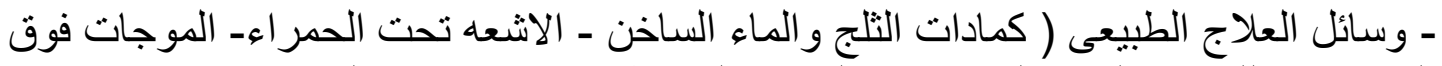

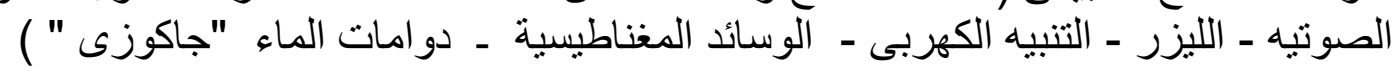

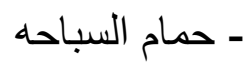

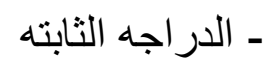
- 2 - عقل حائط

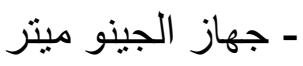
- كر كرات طبيه مختلفه الاوزان

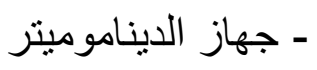
- مشايه كهربائيه

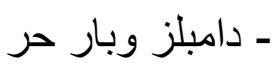

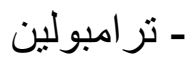

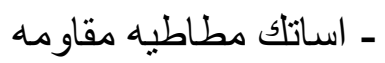

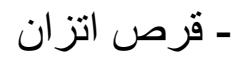
ـ - ساعة إيقاف

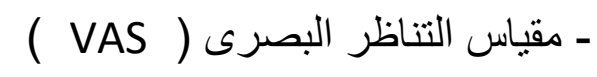
- مر اتب اسفنجية

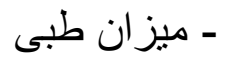
- مواجز بارتفاع متوسط ـ - الريستاميتر لقياس الطول

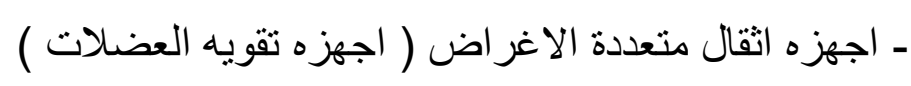

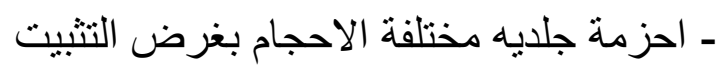
اختيار المساعدون

تم اختيار المساعدون من اخصائى التأهيل البدنى والحركى بأندية فاركو للأدوية و سموحة بقطاع الناشئين قياسات البحث اولا القياسات الاساسية

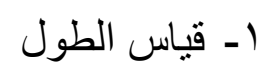

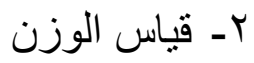

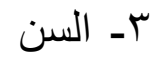

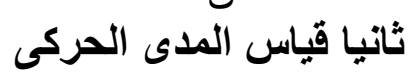

1 - قياس المدى الحركى لثنالقطنيه واسفل الظهر r - قياس المدى الحركى لمد القطنية واسفل الظهر الفرى

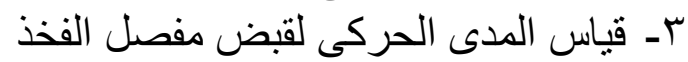
ع - قياس المدى الحركى لبسط مفصل الفيط الفخذ الفذي

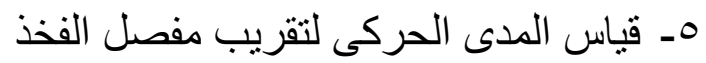
7- قياس المدى الحركى التبعيد مفصل الفخذ الفذي شروط القياس

$$
\begin{aligned}
& \text { 1- الاداء يكون حتى الثعور بالالم }
\end{aligned}
$$

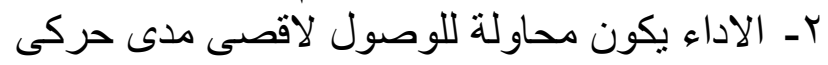

$$
\begin{aligned}
& \text { بـ يتم القياس ثلاث مر ات وتسجل العادل لاعلى نتيجة }
\end{aligned}
$$




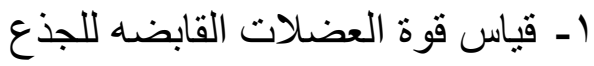

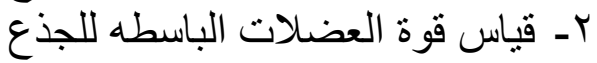

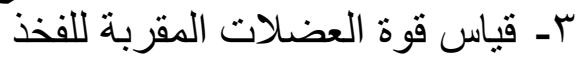

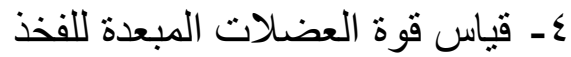

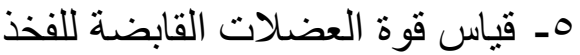
7- قياس قوة العضلات الباسطه للفخذ العضلان لفخد

شروط القياس

ا ـ الاداء بكون حتى الثعور بالالم

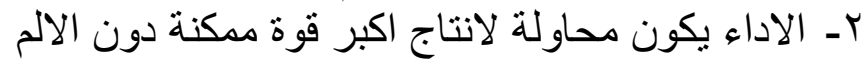

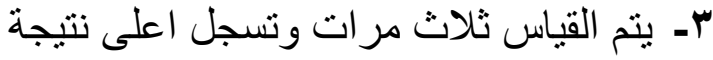

رابعا قياس درجة الالم

يتم قياس درجة الالم عن طريق مقياس التناظر البصرى للألم ( vas ) شكل رقم ( 1 ) مقياس التناظر البصرى للألم ( vas )

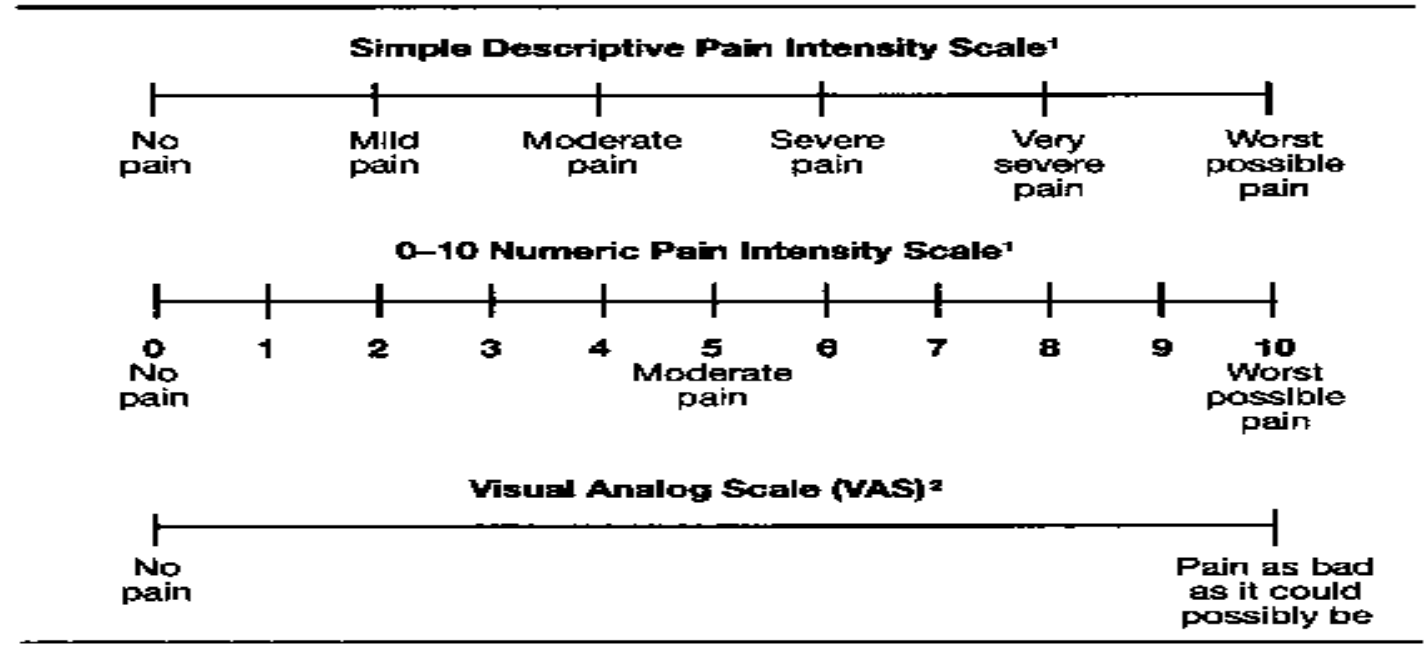

IIf used as a graphic rating scale, a $10 \mathrm{~cm}$ baseline is recomrmended.

2 A 10 -cm begeline is recommencked for VAS scales.

- يقوم المريض بوضع درجة مناسبى للألم الذى يشعر به المريض قبل بداية برنامج التأهيل وقبل بداية

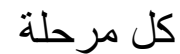

- يتم عمل قياس مرحلى بينى لدرجة الالم اثناء عملية التأهيل وقياس بعد انتهاء برنامج التأهيل والعودة لممارسة النشاط

- يتم القياس مرتين متتاليتين فى يومين متتاليين للتأكد من النتيجه ويكون القياس قبل اداء اداء المجهود البدنى 


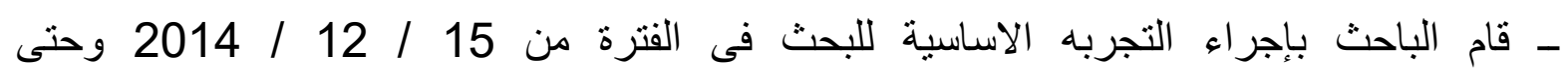
2015/11/29 على الرياضيين الذين قاموا بإجراء جراحة إصلاح الفتق الاربى بطريقة المنظار الجراحى ـ تم عمل القياسات القبليه ( الطول ـ الوزن ـ السن ) قبل الجر احه بيوم واحد

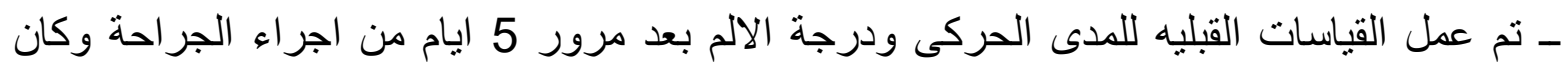

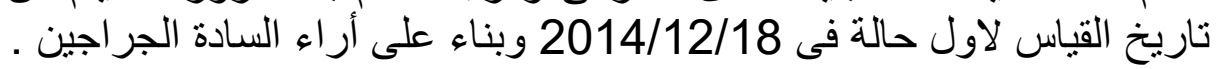

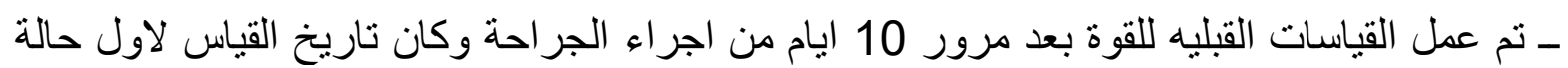

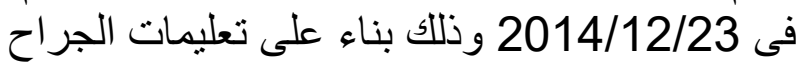

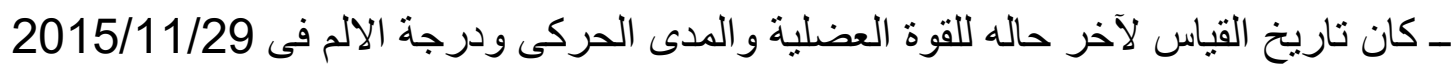

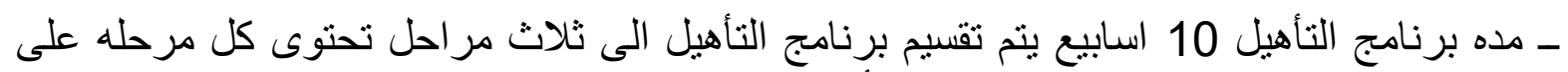
الاهداف المطلوب تحقيقها بنهايه المرحله من أجل الانتقال إلى المرحلة التى تلى تليها

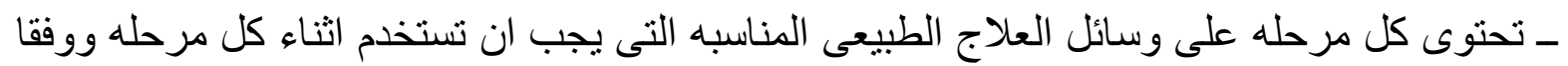

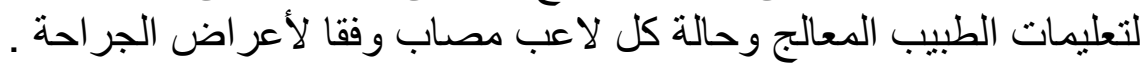

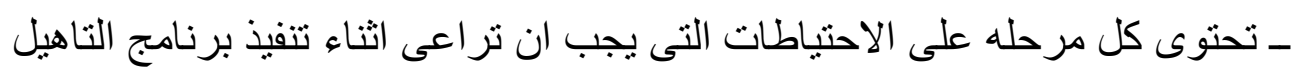

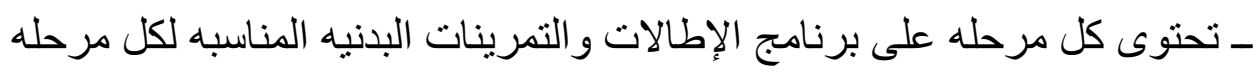

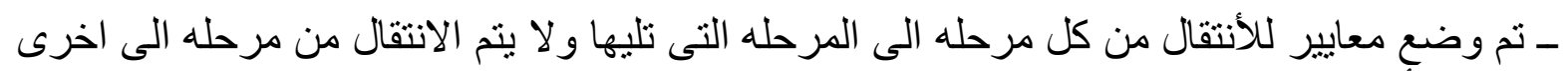

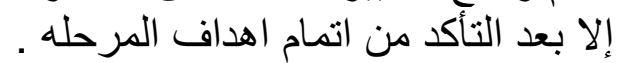

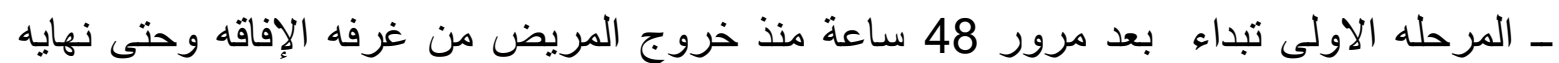

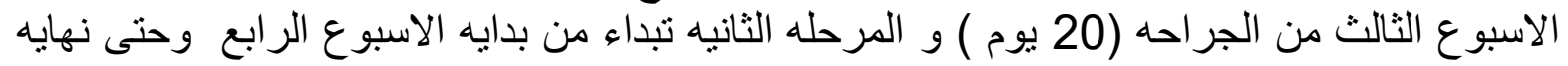

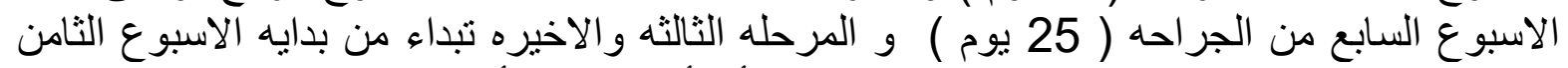

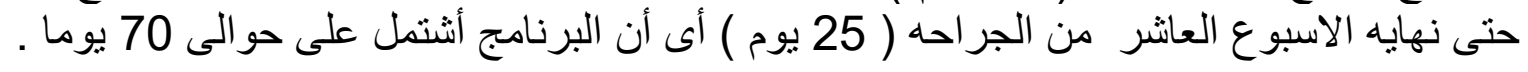

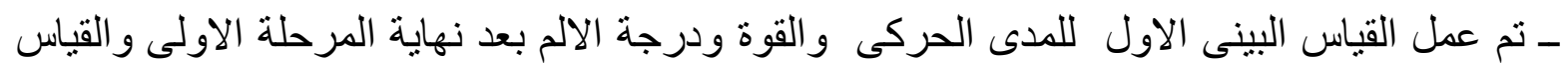

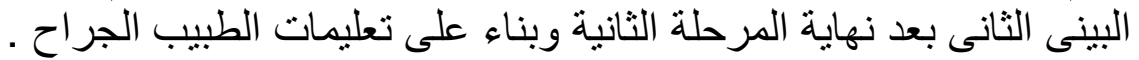

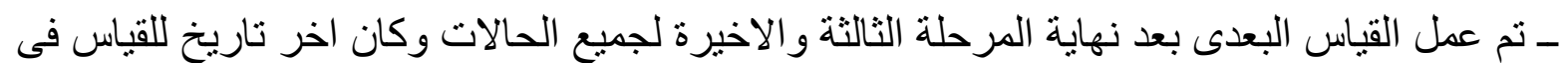
2015/11/29

المرحله الاولى ( الاسبوع الاول والثانى والثالث 2015 يوم) 1- الاهداف :- هناك اهداف رئيسيه من هذه المرحله تتمثل فى

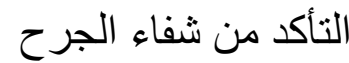

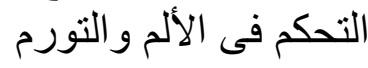

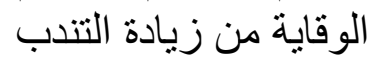
تصريف الارتشاحات المتكونه

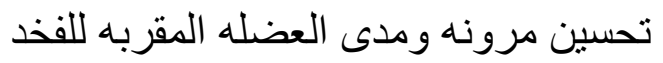
تحسين القوه العضلية للعضله الرباعيه و عضلات خلف الفخذ 
تجنب الإنقباض القوى و المفاجئ لعضله البطن المستقيمه و العضله المقربه للفخذ (

$$
\begin{aligned}
& \text { وسائل التبريد المختلفه cryotherapy } \\
& \text { • التنبيه الكهربى للعضلات التيد } \\
& \text { 4- التدريبات البذنية الليزل المغناطيسى }
\end{aligned}
$$

الششى حتى يصل فى نهايه الاسبوع الثانى للمشى 15 دقيقة مرنين يو ميا

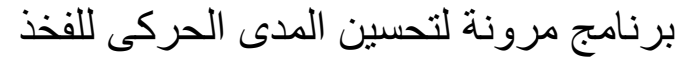

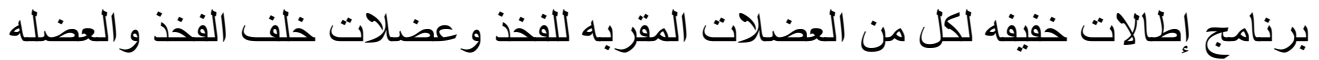

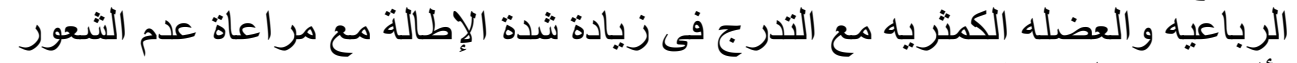
بألم اثناء عمل الإطالات الكذات

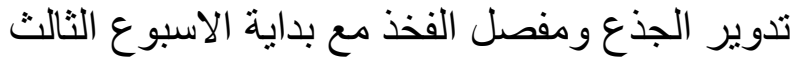

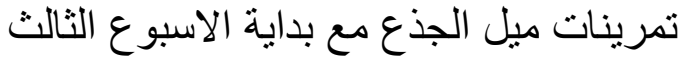
تمرينات قوة العضلات الرباعيه وعضلات الاعبوع خلف الفات الفخذ مع بداية الاسبوع الثالث مع

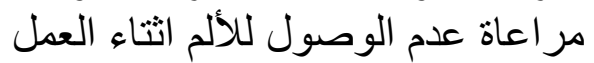

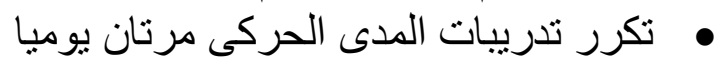
5- 5 - 5عايير الانتقال للمرحله التاليه لا يتم الاتنقال الى المرحله التاليه إلا بعد التأكد من :• عسن المدى الحركى للجز ء القطنى من العمود الفقرى ومفصل الفخذ المرحلة الثانية من برنامج التأهيل ( تبداء من الاسبوع الرابع وحتى نهاية الاسبوع السابع بعد الجراحة 25 يوم ) 1- الاهداف :- هناك اهداف رئيسيه من هذه المرحله تتمثل فى :

$$
\text { تصريف الارتشاحات الألم والتورم المتكونه }
$$

العودة للحركة الطبيعية للفخذ و المنطقه القطنية التطويع المبكر لعضلات البطن المستعرضة و المستقيمه 
ت تجنب الإنقباض القوى و المفاجئ لعضله البطن المستقيمه و العضله المقربه للفخذ

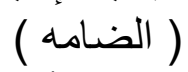
ت تجنب الألم اثناء عمل التمرينات

الاحماء الجيد قبل تمرينات المدى الحركى وتمرينات تقوية العضلات بو اسطه الدراجه الثابته

3- 3 وسائل العلاج الطبيعى

وسائل التبريد المختلفه cryotherapy

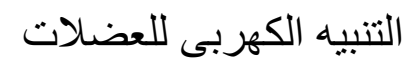

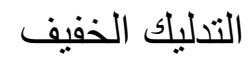

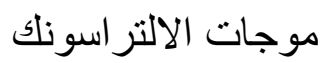

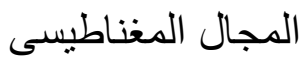

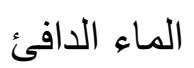

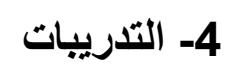

اولا تدريبات المدى الحركى

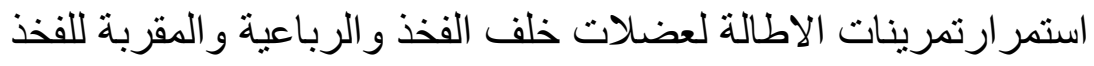

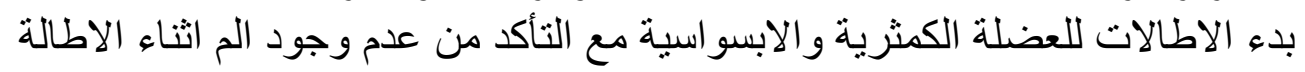

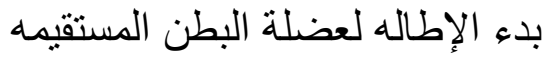

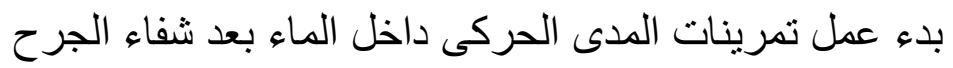
ثانيا تمرينات تحسين كفاءة الجهاز الدورى والتنفسى :

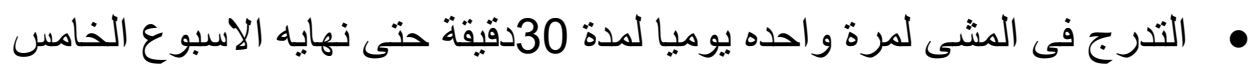

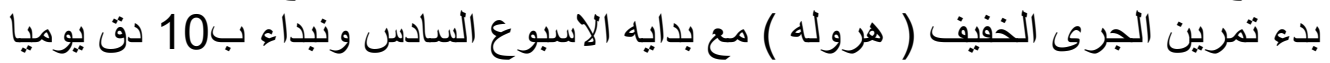

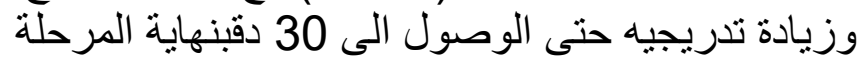

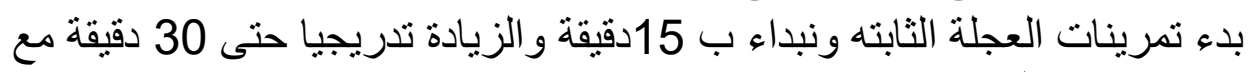

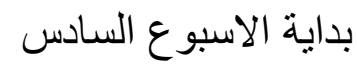

السباحة بعد التأكد من شفاء الجر ح تماما مع مر اعاة عدم الافر اط فى اجهاد الفخذ

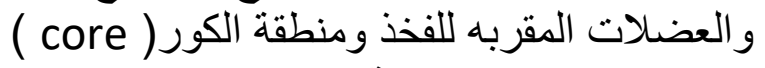
برنامج التأهيل لتحسين القوة العضلية :

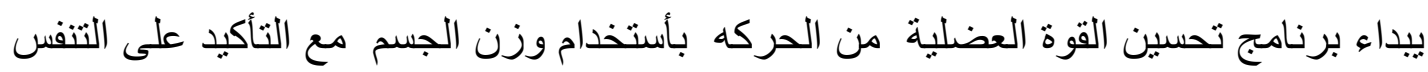

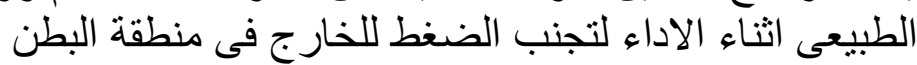

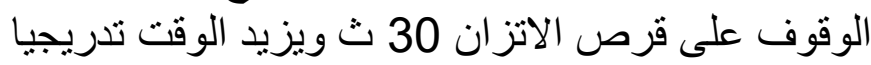

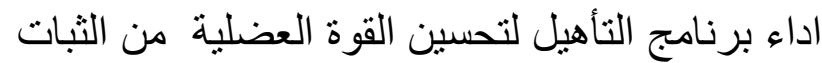

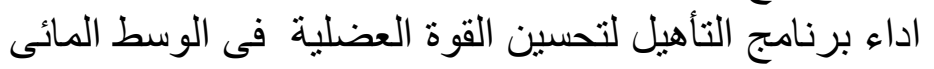
5- معايير الانتقال للمرحله التاليه

لا يتم الانتقال الى المرحله التاليه إلا بعد التأكد من :-

$$
\text { زوال الألم اثناء الهرولة }
$$


• • تحسن حركه العمود الفقرى ومفصل الفخذ

المرحلة الثالثة والاخيرة من برنامج التأهيل

(تبداء من بدايه الاسبوع الثامن حتى نهايه الاسبوع العاشر من الجراحه 21 يوم )

1- الاهداف :- هناك اهداف رئيسيه من هذه المرحله تتمثل فى

زيادة قوة عضلات البطن المستعرضها و العضله المقربه للفخذ للعوده الى قوتهما قبل اجر اء

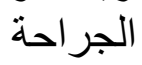

الع زيادة التحمل العضلى و التحمل الدورى التتفسى و الرشاقه

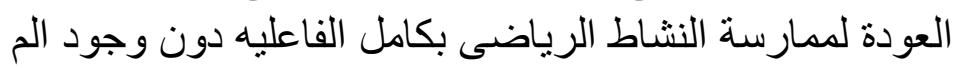

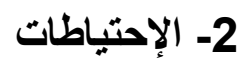

• تجنب الألم اثثاء عمل التمرينات المبات

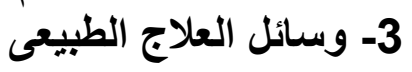

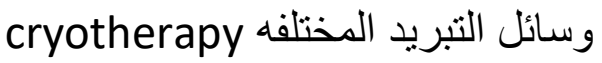

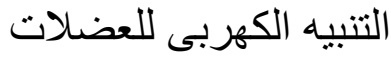

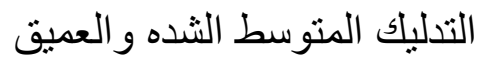

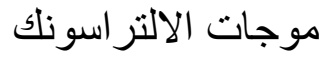

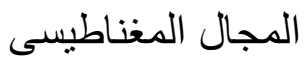

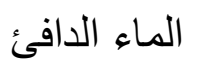

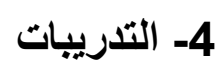

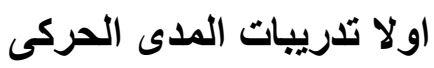

استمر ارتمرينات الاطالة لجميع العضلات حول الحوض للوصول الى معدلات الطول

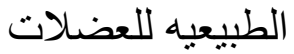

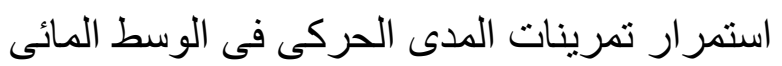

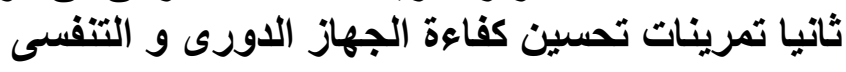

• تمرينات الجرى بأثنكالها المختلفه مع مر اعات تجنب البدء القوى او التوقف المفاجئ

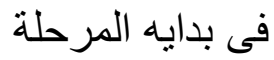

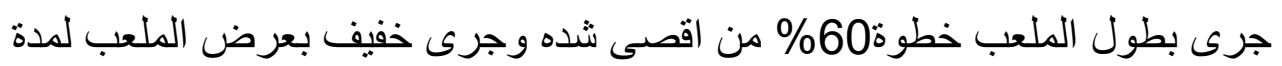

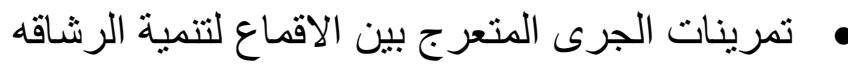

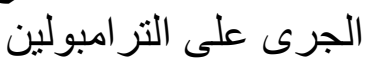

استمر ار تمرينات العجلة الثابته وير اعى الزياده المتدرجه في حجم وشده التمرين

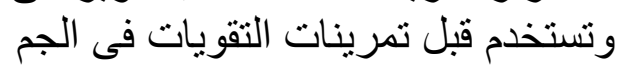

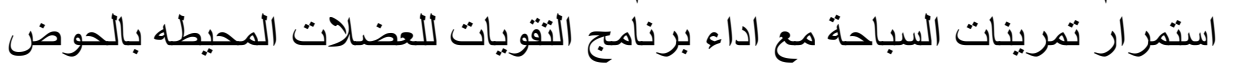

برنامج التأهيل لتحسين القوة العضلية : • الوقوف على قرص الاتزان بزمن مندرج 


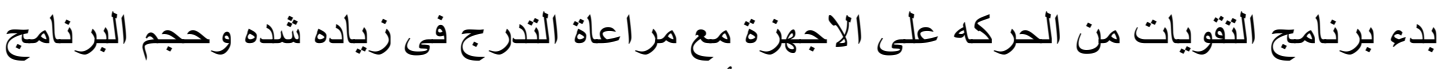

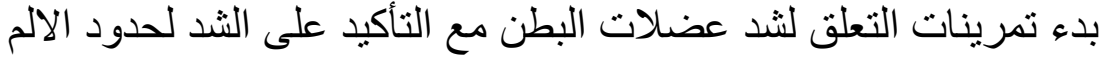

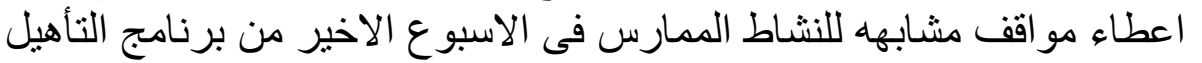
5- معايير العوده الى ممارسة النشاط بصورة كامله النئ.

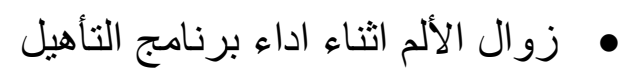
• عدم وجود الم الثناء تمرينات الجرى باقصى سرعة ( اسبرينت ) وتمرينات تغيير الاتجاه

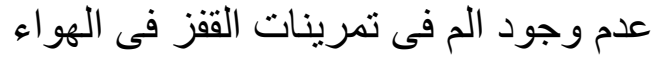

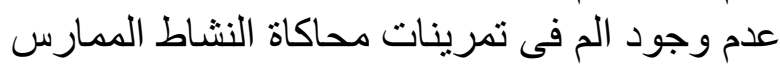

أولاً : عرض النتائج : مان عرض نتائج قياسات المدى الحركي لعينة الدراسة : جدول ( 2 ) المتوسط الحسابى والانحراف المعيارى للقياسات المتكررة (القبلى ،البينى الأول ، البينى الثانى ، البعدى) فى قياسات المدى الحركى لمفصل الفخذ على الرجل جهة الجراحة $6=\dot{0}$

\begin{tabular}{|c|c|c|c|c|c|c|c|c|}
\hline \multicolumn{2}{|c|}{ القياس البعدى } & \multicolumn{2}{|c|}{ البينى الثانى } & \multicolumn{2}{|c|}{ البينى الاول } & \multicolumn{2}{|c|}{ القياس القبلى } & \multirow{2}{*}{ القياسات } \\
\hline$\varepsilon \pm$ & س- س & $\varepsilon \pm$ & س- ا ك- & $\varepsilon \pm$ & س- ا ك- & $\varepsilon \pm$ & 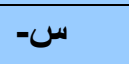 & \\
\hline 2.229 & 24.83 & 2.168 & 23.50 & 3.061 & 19.17 & 3.430 & 9.83 & تقريب مفصل للفذذ \\
\hline 3.983 & 34.33 & 3.017 & 32.50 & 4.546 & 25.33 & 3.764 & 10.17 & تبعيد مفصل الفذذ \\
\hline 6.723 & 120 & 6.274 & 118.83 & 9.439 & 106.50 & 12.879 & 62.33 & قبض مفصل الفخذ \\
\hline 1.871 & 17.50 & 2.258 & 15.50 & 3.488 & 8.83 & 0.408 & 0.17 & بسط مفصل الفخذ \\
\hline
\end{tabular}

يتضح من الجدول رقم ( 2 ) و الخاص بالمتوسط الحسابى والانحر اف المعيارى وجود فروق

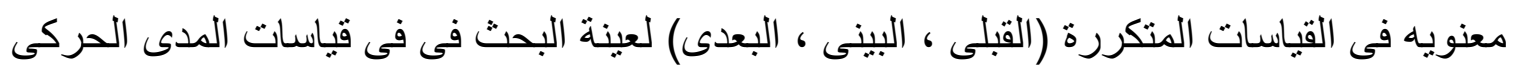
لمفصل الفخذ على الرجل جهة الجر احة.

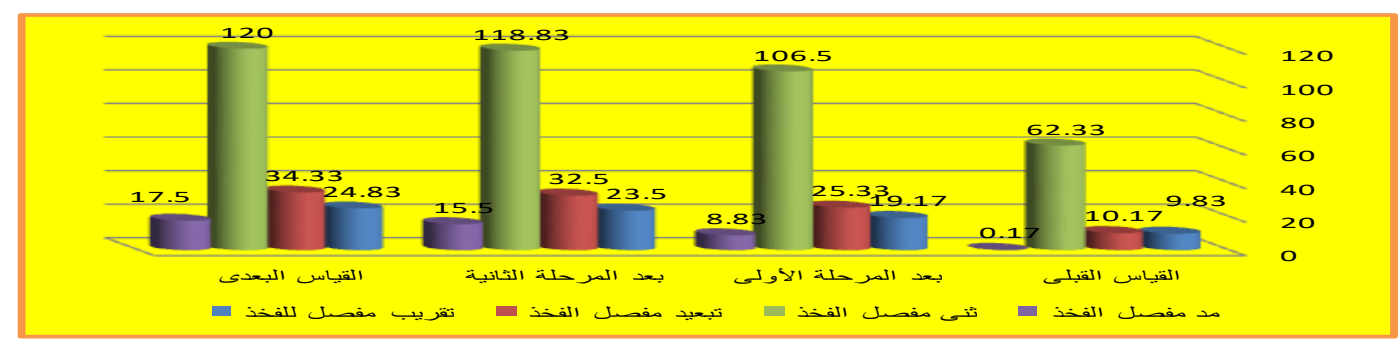

شكل رقم ( 2) يوضح المتوسط الحسابي للقياسات المتكررة (القبلى ، المرحلى الأول ، المرحلى الثانى ، البعدى) فى قياسات المدى الحركى لمفصل الفخذ على الرجل جهة الجراحة 
جدول ( 6 ) المتوسط الحسابى والانحراف المعيارى ونسبة التحسن وقيمة " ت " المحسوبة بين القياس القبلى والبعدى فى قياسات المدى الحركى لمفصل الفذذ على الرجل جهة الجراحة

\begin{tabular}{|c|c|c|c|c|c|c|c|c|c|}
\hline \multicolumn{2}{|c|}{ التأثير } & \multirow[b]{2}{*}{ " قل ت " قيمة } & \multirow[b]{2}{*}{$\begin{array}{c}\text { التحسبة } \\
\text { \% }\end{array}$} & \multirow[b]{2}{*}{ المتوسطين } & \multicolumn{2}{|c|}{ القياس البعدى } & \multicolumn{2}{|c|}{ القياس القبلى } & \multirow[b]{2}{*}{ القياسات } \\
\hline مقدار & قلتيمة & & & & $\varepsilon \pm$ & س- - & $\varepsilon \pm$ & س- & \\
\hline مرتفع & 4.937 & **12.68 & 152.59 & 15.00 & 2.229 & 24.83 & 3.430 & 9.83 & تقريب مفصل للفذخ \\
\hline مرتفع & 6.237 & ${ }^{* * 9.44}$ & 237.65 & 24.17 & 3.983 & 34.33 & 3.764 & 10.17 & تبعيد مفصل الفذذ \\
\hline مرتفع & 5.168 & $* * 12.67$ & 92.52 & 57.67 & 6.723 & 120 & 12.879 & 62.33 & قبض مفصل الفخذ \\
\hline مرتفع & 8.817 & $* * 26.00$ & 10194.11 & 17.33 & 1.871 & 17.50 & 0.408 & 0.17 & بسط مفصل الفذذ \\
\hline
\end{tabular}

"معنوية " ت " الجدولية عند مستوى 2.032 = 2.05 ، عند مستوى 0.01 =

يتضح من الجدول رقم ( 6 ) وجود فروق ذات دلالـة معنويـة فـى قيهـة " ت " الدحسوبة بين

القياس قبلى و البعدى فى قياسات المدى الحركى لمفصل الفخذ على الرجل جهـة الجر احسة ، وتر اوحت

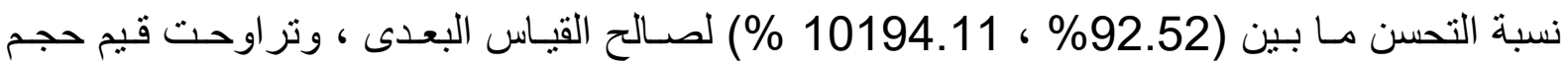

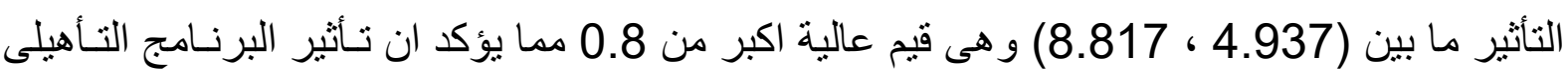
مرتفع فى جميع المتغيرات لعينة البحث.

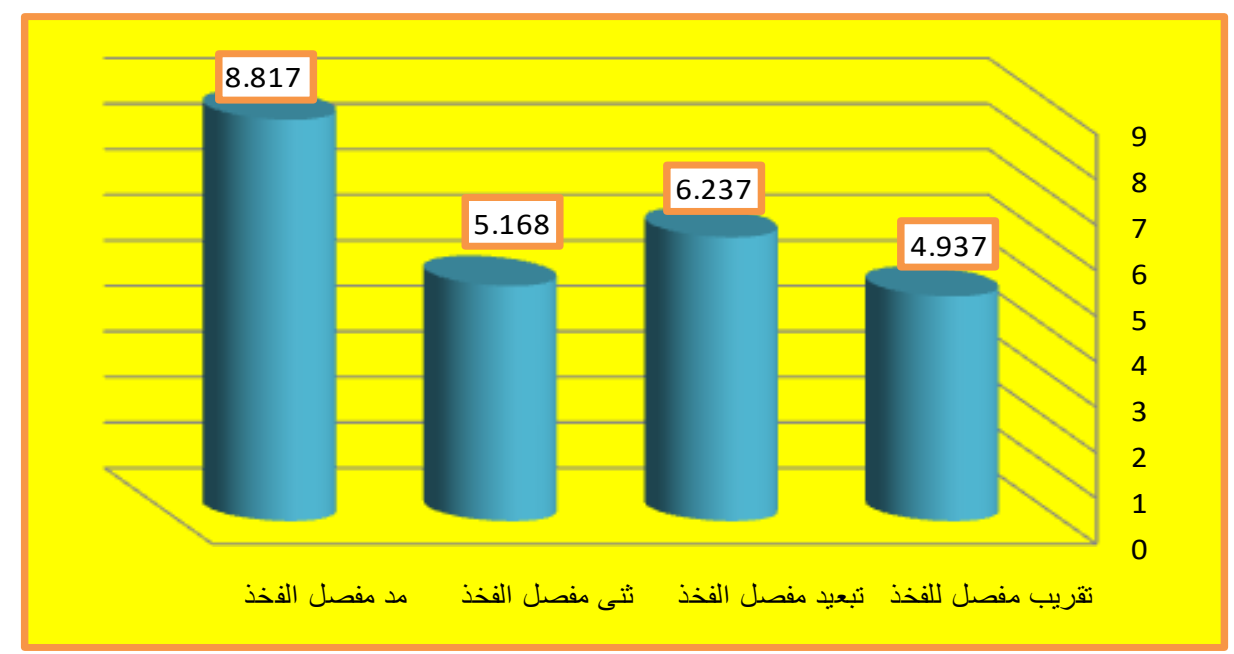

شكل رقم ( 3 ) يوضح قيمة حجم التأثير لقياسات المدى الحركى لمفصل الفذذ على الرجل جهة الجراحة 
جدول ( 7 ) المتوسط الحسابى والانحراف المعيارى للقياسات المتكررة (القبلى ،البينى الأول ، البينى

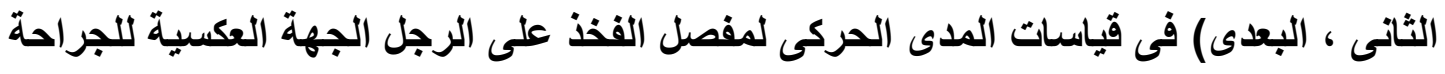
ن

\begin{tabular}{|c|c|c|c|c|c|c|c|c|}
\hline \multicolumn{2}{|c|}{ القياس البعدى } & \multicolumn{2}{|c|}{ البينى الثانى } & \multicolumn{2}{|c|}{ البينى الاول } & \multicolumn{2}{|c|}{ القياس القبلى } & \multirow{2}{*}{ القياسات } \\
\hline$\varepsilon \pm$ & 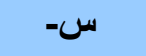 & $\varepsilon \pm$ & س- & $\varepsilon \pm$ & س- & $\varepsilon \pm$ & س- & \\
\hline 2.160 & 24.67 & 2.317 & 24.17 & 4.803 & 21.33 & 4.885 & 13.67 & تقريب مفصل للفذذ \\
\hline 4.320 & 34.67 & 4.885 & 34.33 & 8.183 & 30.17 & 2.639 & 13.17 & تبعيد مفصل الفذذ \\
\hline 6.616 & 119.83 & 6.633 & 119.00 & 10.526 & 112.00 & 16.884 & 70.67 & قبض مفصل الفخذ \\
\hline 2.168 & 17.50 & 2.787 & 16.17 & 4.690 & 10.00 & 0.408 & 0.17 & بسط مفصل الفذذ \\
\hline
\end{tabular}

يتضح من الجدول رقم ( 7 ) و الخاص بالمتوسط الحسابى و الانحر اف المعيـارى وجود فروق

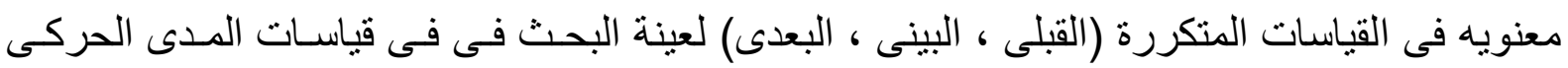
لمفصل الفخذ على الرجل الجهة العكسية للجر احة.

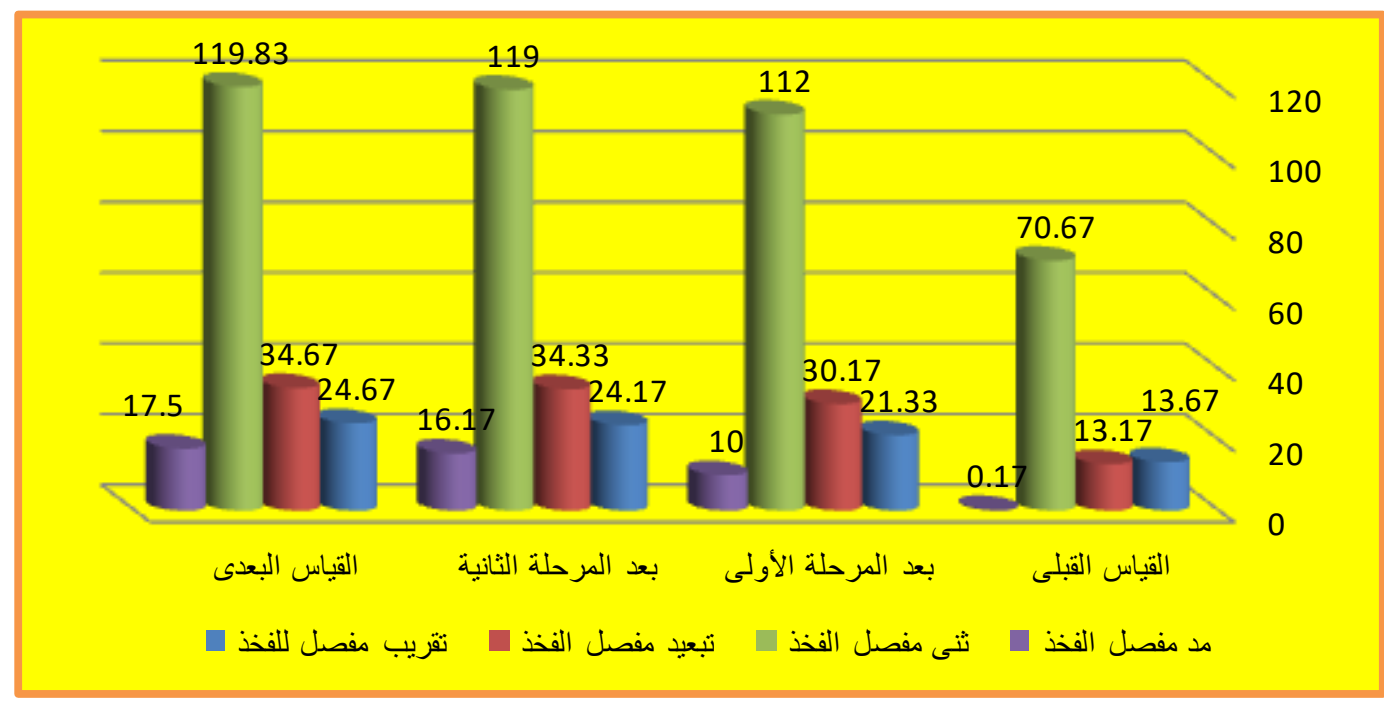

شكل رقم ( 4 ) يوضح المتوسط الحسابي للقياسات المتكررة (القبلى ، البينى الاول ،البينى الثانى ، البعدى) فى قياسات المدى العركى لمفصل الفذذ على الرجل الجهة العكسية للجراحة 


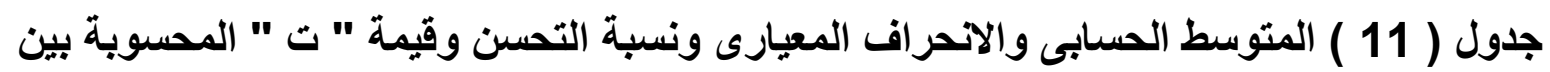
القياس القبلى والبعدى فى قياسات المدى الحركى لمفصل الفذذ على الرجل الجهة العهية العكية للجراحة

\begin{tabular}{|c|c|c|c|c|c|c|c|c|c|}
\hline \multicolumn{2}{|c|}{ التأثير } & \multirow[b]{2}{*}{ " قيمة " } & \multirow[b]{2}{*}{$\begin{array}{c}\text { التحسنة } \\
\text { \% }\end{array}$} & \multirow[b]{2}{*}{ المترسطين بين } & \multicolumn{2}{|c|}{ القياس البعدى } & \multicolumn{2}{|c|}{ القياس القبلى } & \multirow[b]{2}{*}{ القياسـات } \\
\hline مقدار & قيمة & & & & $\varepsilon \pm$ & س- & $\varepsilon \pm$ & س- & \\
\hline مرتفع & 2.355 & **7.10 & 80.46 & 11.00 & 2.160 & 24.67 & 4.885 & 13.67 & تقريب مفصل \\
\hline مرتفع & 5.585 & **15.02 & 163.24 & 21.50 & 4.320 & 34.67 & 2.639 & 13.17 & تبعيد مفصل الفخذ \\
\hline مرتفع & 3.619 & $* * 7.37$ & 69.58 & 49.17 & 6.616 & 119.83 & 16.884 & 70.67 & قبض مفصل الفخذ \\
\hline مرتفع & 6.019 & **22.80 & 10194.11 & 17.33 & 2.168 & 17.50 & 0.408 & 0.17 & بسط مفصل الفخذ \\
\hline
\end{tabular}

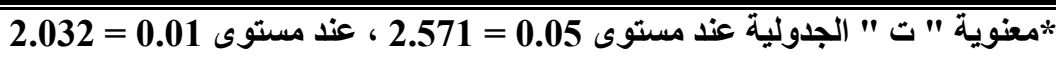

يتضح من الجدول رقم ( 11 ) وجود فروق ذات دلالة معنويـة فى قيمـة " ت " المحسوبة بـين

القياس قبلى و البعدى فى قياسات المدى الحركى لمفصل الفخذ على الرجل الجهة العكسية للجراحـة ،

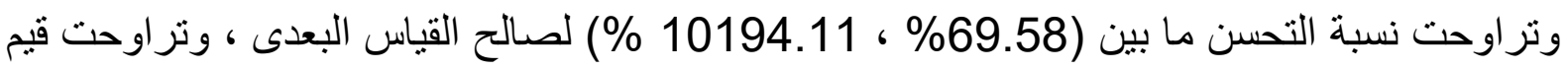

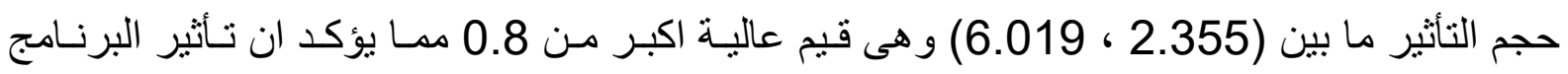
التأهيلى مرتفع فى جميع المتغير ات لعينة البحث.

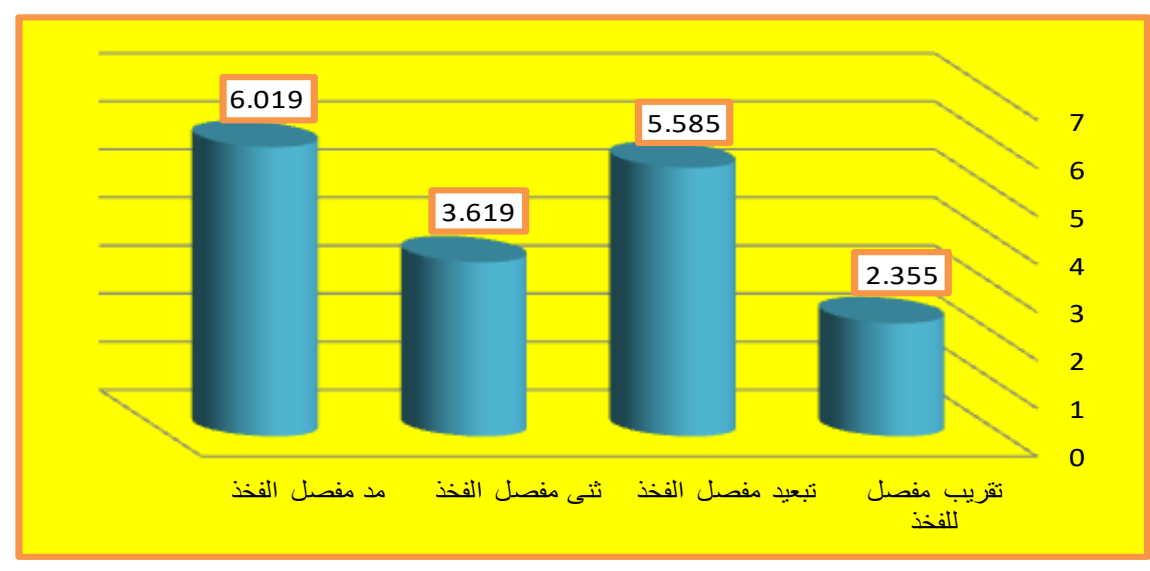

شكل رقم ( 5) يوضح قيمة حجم التأثير لقياسات المدى الحركى لمفصل الفخذ على الرجل الجهة العكسية للجراحة

جدول ( 12 ) المتوسط الحسابى والانحراف المعيارى للقياسات المتكررة (القبلى ، البينى الاول ،

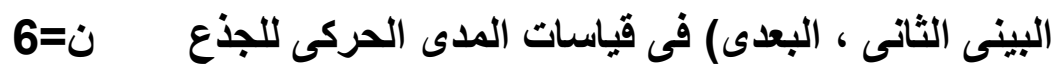




\begin{tabular}{|c|c|c|c|c|c|c|c|c|}
\hline \multicolumn{2}{|c|}{ القياس البعدى } & \multicolumn{2}{|c|}{ القياس البينى الثانى } & \multicolumn{2}{|c|}{ القياس البينى الاول } & \multicolumn{2}{|c|}{ القياس القبلى } & \multirow{2}{*}{ القياسات } \\
\hline$\varepsilon \pm$ & س- & $\varepsilon \pm$ & س- & $\varepsilon \pm$ & 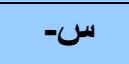 & $\varepsilon \pm$ & س- & \\
\hline 4.167 & 81.83 & 5.550 & 76.00 & 13.352 & 49.33 & 2.858 & 10.17 & قبض القطنية واسفل الظهر \\
\hline 4.320 & 22.33 & 3.950 & 20.00 & 3.189 & 13.83 & 0.408 & 0.17 & بسط القطنية و اسفل الظهر \\
\hline
\end{tabular}

يتضح من الجدول رقم ( 12 ) والخاص بالمتوسط الحسابى والانحر اف المعيارى وجود فروق

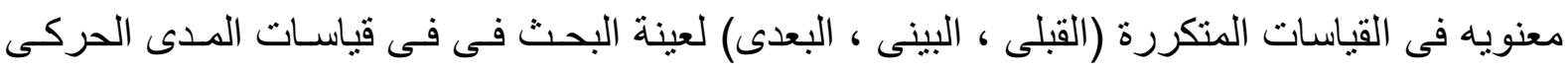
للجذع.

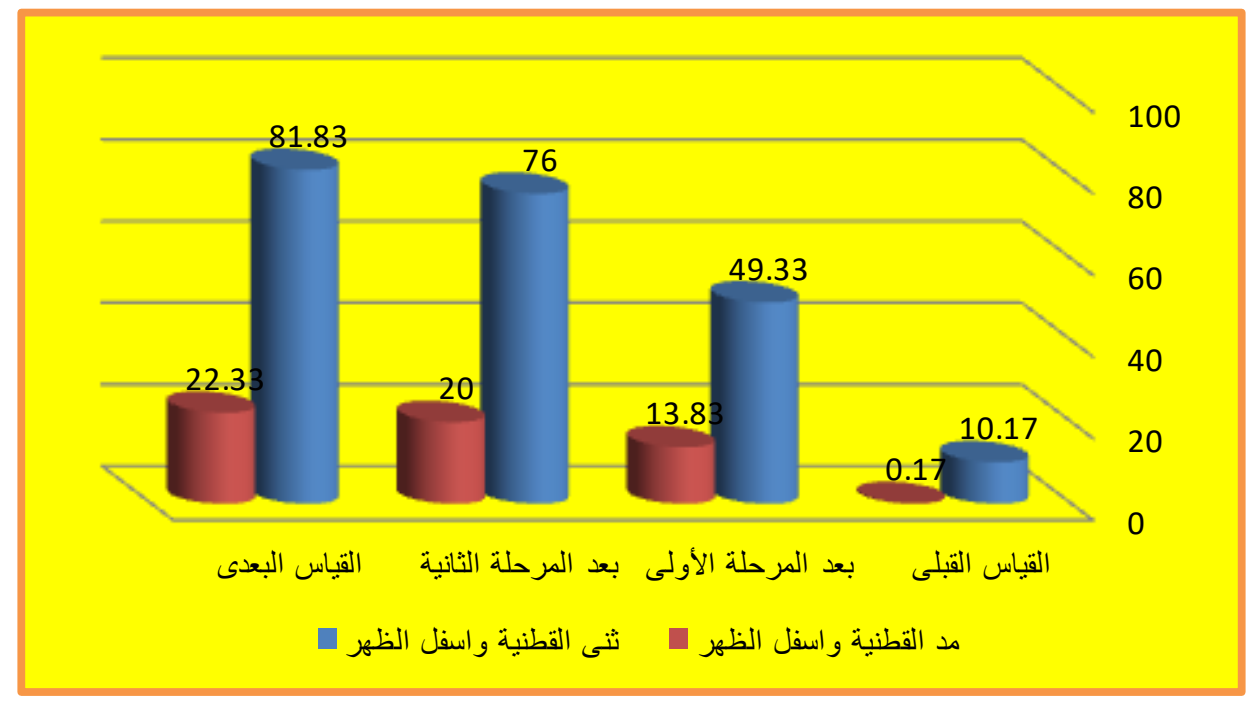

شكل رقم ( 6 ) يوضح المتوسط الحسابي للقياسات المتكررة (القبلى ، البينى الاول ، البينى الثانى ،

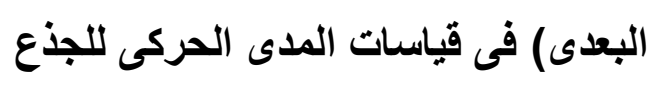

جدول ( 16 ) المتوسط الحسابى والانحراف المعيارى ونسبة التحسن وقيمة " ت " المحسوية بين القياس القبلى والبعدى فى قياسات المدى الحركى للجذع ونئ

\begin{tabular}{|c|c|c|c|c|c|c|c|c|c|}
\hline \multicolumn{2}{|c|}{ التأثير } & \multirow[b]{2}{*}{ " قت " } & \multirow[b]{2}{*}{$\begin{array}{c}\text { التحسنة } \\
\text { \% }\end{array}$} & \multirow[b]{2}{*}{ المترسط بين } & \multicolumn{2}{|c|}{ القياس البعدى } & \multicolumn{2}{|c|}{ القياس القبلى } & \multirow[b]{2}{*}{ القياسات } \\
\hline مقدار & قاتئة & & & & $\varepsilon \pm$ & س- & $\varepsilon \pm$ & س- & \\
\hline مرتفع & 19.849 & **39.39 & 704.71 & 71.67 & 4.167 & 81.83 & 2.858 & 10.17 & قوبض القطنية \\
\hline
\end{tabular}




\begin{tabular}{|c|c|c|c|c|c|c|c|c|c|}
\hline مرتفع & 6.214 & $* * 12.88$ & 13041.17 & 22.17 & 4.320 & 22.33 & 0.408 & 0.17 & واسفل الظهر القطنية \\
\hline
\end{tabular}

"معنوية " ت " الجدولية عذد مستوى 0.05 = 2.571 ، عند مستوى 0.01 = 2.012

يتضح من الجدول رقم ( 16 ) وجود فروق ذات دلالة معنويـة فى قيمـة " ت " المحسوبة بـين

القياس قبلى و البعدى فى قياسات المدى الحركى للجذع ، وتر اوحت نسبة التحسن ما بين (704.71 \% ، 13041.17\% لصالح القياس البعدى ، ونراوحت قيم حجم التأثير مـا بـين (6.214 ، 19.849)

و هي قيم عالية اكبر من 0.8 مما يؤكد ان تأثير البرنـامج التـأهيلى مرتفع فى جميع المتغير ات لعينـة البحث.

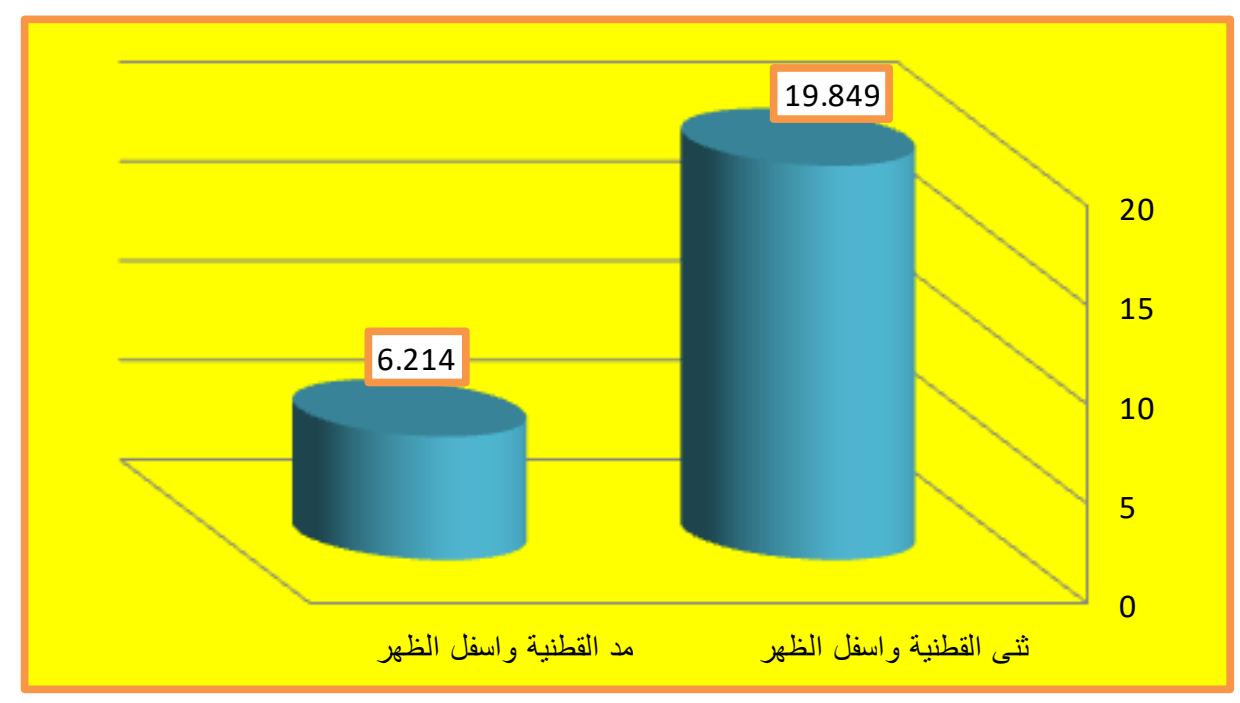

شكل رقم ( 7 ) يوضح قيمة حجم التأثير لقياسات المدى الحركى للجذع

عرض نتائج قياسات القوة العضلية لعينة الاراسة :

جدول ( 17 ) المتوسط الحسابى والاتحراف المعيارى للقياسات المتكررة (القبلى ، بعد المرحلة الأولى ، بعد المرحلة الثانية ، البعدى) فى قياسات القوة العضلية لمفصل الفخذ على الرجل جهة الجراحة

\begin{tabular}{|c|c|c|c|c|c|c|c|c|}
\hline \multicolumn{2}{|c|}{ القياس البعدى } & \multicolumn{2}{|c|}{ القياس البينى الثانى } & \multicolumn{2}{|c|}{ القياس البينى الاول } & \multicolumn{2}{|c|}{ القياس القبلى } & \multirow{2}{*}{ القياسات } \\
\hline$\varepsilon \pm$ & 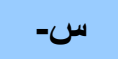 & $\varepsilon \pm$ & س- & $\varepsilon \pm$ & س- & $\varepsilon \pm$ & س- & \\
\hline 4.401 & 30.83 & 3.817 & 22.83 & 2.563 & 10.83 & 0.548 & 1.00 & قوة العضلات المقربة للفخذ \\
\hline 3.742 & 28.00 & 3.674 & 21.50 & 2.317 & 7.83 & 0.476 & 0.43 & قوة العضلات المبعدة للفخذ \\
\hline 2.563 & 37.83 & 4.021 & 29.83 & 3.017 & 13.50 & 0.418 & 0.75 & قوة العضلات القابضة للفذذ \\
\hline 2.338 & 33.67 & 2.881 & 27.50 & 2.366 & 11.00 & 0.360 & 0.68 & قوة العضلات الباسطه للفخذ \\
\hline
\end{tabular}


يتضح من الجدول رقم (17 ) والخاص بالمتوسط الحسابى و الانحر اف المعيارى وجود فروق معنويه فى القياسات المتكررة (القبلى ، البينى ، البعدى) لعينة البحث فى فياسات القوة العضلية لمفصل الفخذ على الرجل جهة الجر احة.

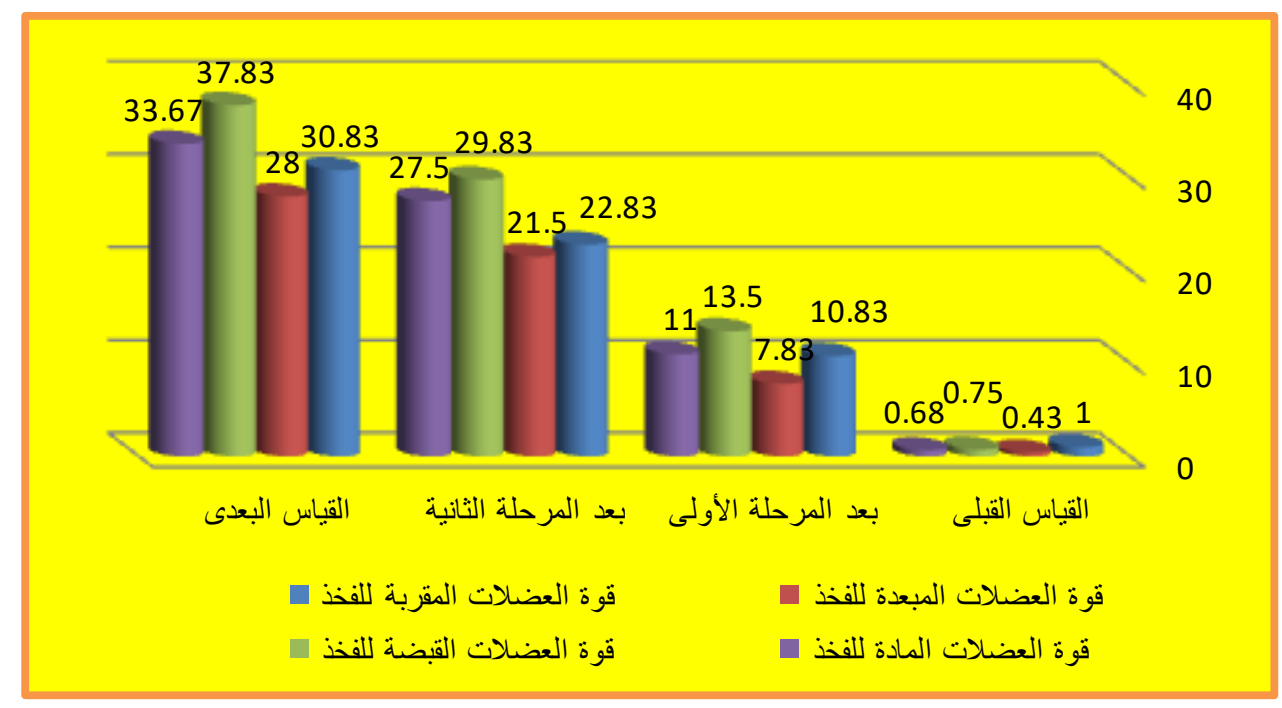

شكل رقم ( 8 ) يوضح المتوسط الحسابي للقياسات المتكررة (القبلى ، البينى الاول ، البينى الثانى ، البعى) فى قياسات القوة العضلية لمفصل الفذذ على الرجل جهة الجراحة

\begin{tabular}{|c|c|c|c|c|c|c|c|c|c|}
\hline مرتفع & 23.036 & **32.44 & 4944 & 37.08 & 2.563 & 37.83 & 0.418 & 0.75 & لعضلات القابضة \\
\hline مرتفع & 12.065 & **38.47 & 4850 & 32.98 & 2.338 & 33.67 & 0.360 & 0.68 & قالباسطه للفضلات \\
\hline
\end{tabular}

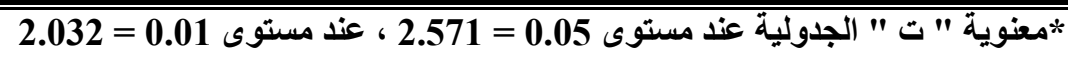

يتضح من الجدول رقم ( 21 ) وجود فروق ذات دلالة معنويـة فى قيمـة " ت " المحسوبة بين

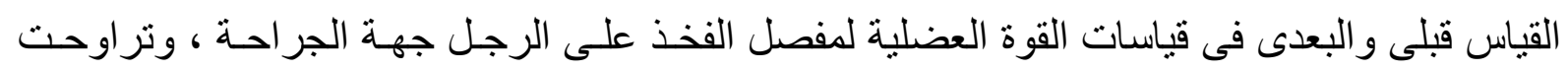
نسبة التحسن ما بين (2983\% ، 6361.62 \% \% لصالح القياس البعدى ، وتراوحت قيم حجم التأثير

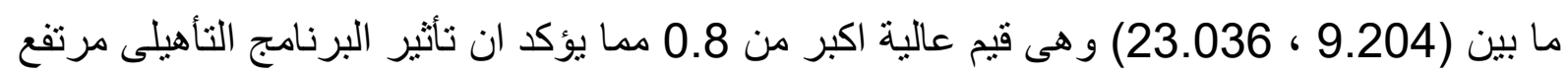
فى جميع المتغير ات لعينة البحث. 


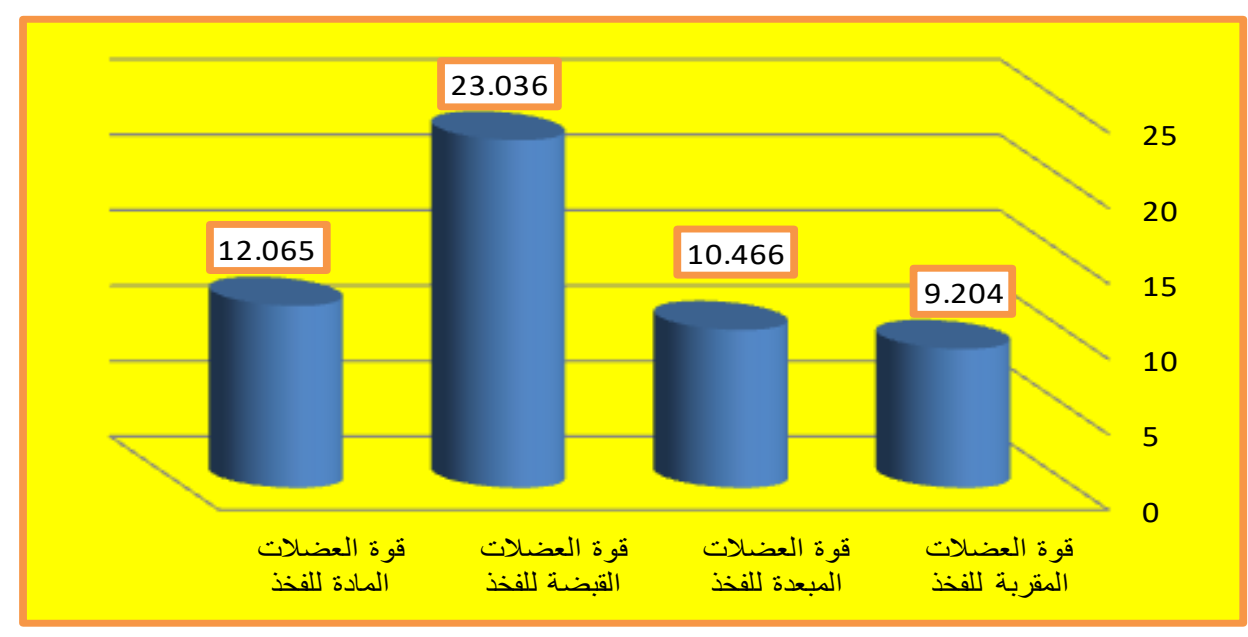

شكل رقم ( 9) يوضح قيمة حجم التأثير لقياسات القوة العضلية لمفصل الفخذ على الرجل جهة الجراحة

جدول ( 22 ) المتوسط الحسابى والانحراف المعيارى للقياسات المتكررة (القبلى ، البينى الاول ،

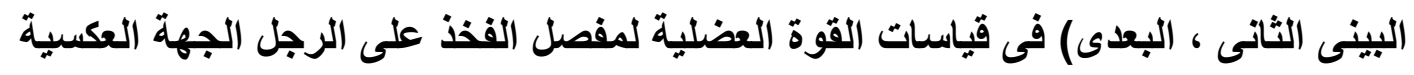
لاحزة

\begin{tabular}{|c|c|c|c|c|c|c|c|c|}
\hline \multicolumn{2}{|c|}{ القياس البعدى } & \multicolumn{2}{|c|}{ بعد المرحلة الثانية } & \multicolumn{2}{|c|}{ بعد المرحلة الأولى } & \multicolumn{2}{|c|}{ القياس القبلى } & \multirow[t]{2}{*}{ القياستات } \\
\hline$\varepsilon \pm$ & س- & $\varepsilon \pm$ & س- & $\varepsilon \pm$ & س- س & $\varepsilon \pm$ & س- & \\
\hline 4.803 & 30.33 & 2.881 & 22.50 & 4.633 & 15.67 & 0.258 & 0.83 & قوة العضلات المقربة للفخذ \\
\hline 1.966 & 29.33 & 3.141 & 23.67 & 2.483 & 14.83 & 0.204 & 0.92 & قوة العضلات المبعدة للفخذ \\
\hline 1.517 & 36.50 & 1.211 & 31.33 & 1.549 & 14.00 & 0.516 & 1.33 & قوة العضلات القابضة للفخذ \\
\hline 1.378 & 32.50 & 1.095 & 26.00 & 2.429 & 12.50 & 0.204 & 0.92 & قوة العضلات الباسطه للفخذ \\
\hline
\end{tabular}

يتضح من الجدول رقم ( 22 ) و الخاص بالمتوسط الحسابى والانحر اف المعيارى وجـود فروق معنويه فى للقياسات المتكررة (القبلى ، البينى ، البعدى) لعينة البحث فى قياسات القوة العضلية لمفصـل لهـل الفخذ على الرجل الجهة العكسية للجر احة . 


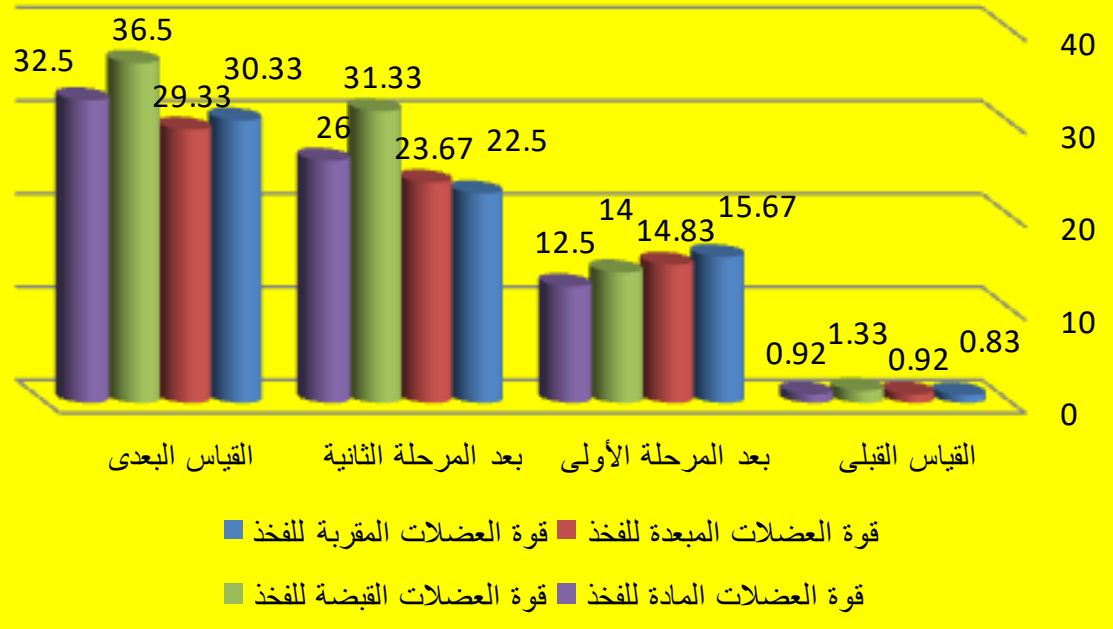

شكل رقم ( 10 ) يوضح المتوسط الحسابي للقياسات المتكررة (القبلى ، البينى الاول ، البينى الثانى ،

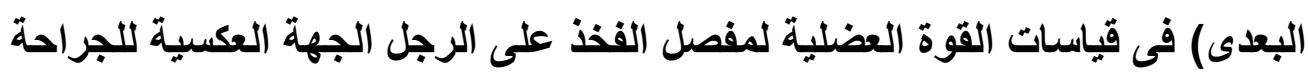

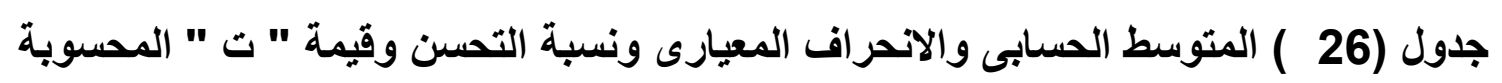
بين القياس القبلى والبعدى فى قياسـات القوة العضلية لمفصل الفخذ على الرجل الجهـة العكسية للجراحة

\begin{tabular}{|c|c|c|c|c|c|c|c|c|c|}
\hline \multicolumn{2}{|c|}{ التأثير } & \multirow[b]{2}{*}{ " قل " " } & \multirow[b]{2}{*}{$\begin{array}{c}\text { التحسن } \\
\text { \% }\end{array}$} & \multirow[b]{2}{*}{ المتوسطين } & \multicolumn{2}{|c|}{ القياس البعدى } & \multicolumn{2}{|c|}{ القياس القبلى } & \multirow[b]{2}{*}{ القياسات } \\
\hline مقدار & قاتئمة & & & & $\varepsilon \pm$ & س- & $\varepsilon \pm$ & س- & \\
\hline مرتفع & 9.633 & ** 14.81 & 3554.21 & 29.50 & 4.803 & 30.33 & 0.258 & 0.83 & المقرة العضلات للفذذ \\
\hline مرتفع & 25.806 & **32.31 & 3089.13 & 28.42 & 1.966 & 29.33 & 0.204 & 0.92 & قالوة العضلات للفذذ \\
\hline مرتفع & 34.053 & **44.38 & 2644.36 & 35.17 & 1.517 & 36.50 & 0.516 & 1.33 & القوة العضلات للفذذ \\
\hline مرتفع & 23.823 & $* * 60.38$ & 3432.60 & 31.58 & 1.378 & 32.50 & 0.204 & 0.92 & البوة العضلات للفذذ \\
\hline
\end{tabular}

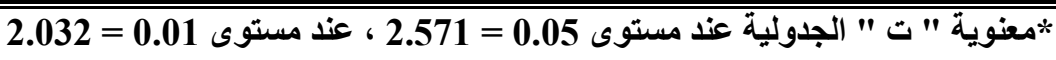

يتضح من الجدول رقم ( 26 ) وجود فروق ذات دلالة معنويـة فى قيمـة " ت " المحسوبة بين

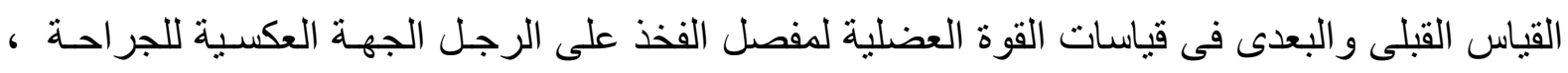


وتراوحت نسبة التحسن ما بين (2644.36\% ، 3554.21 \%) لصالح القياس البعدى ، وتراوحت

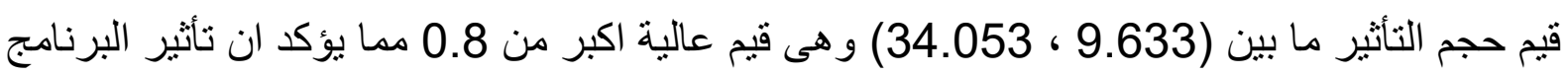
التأهيلى مرتفع فى جميع المتغير ات لعينة البحث.

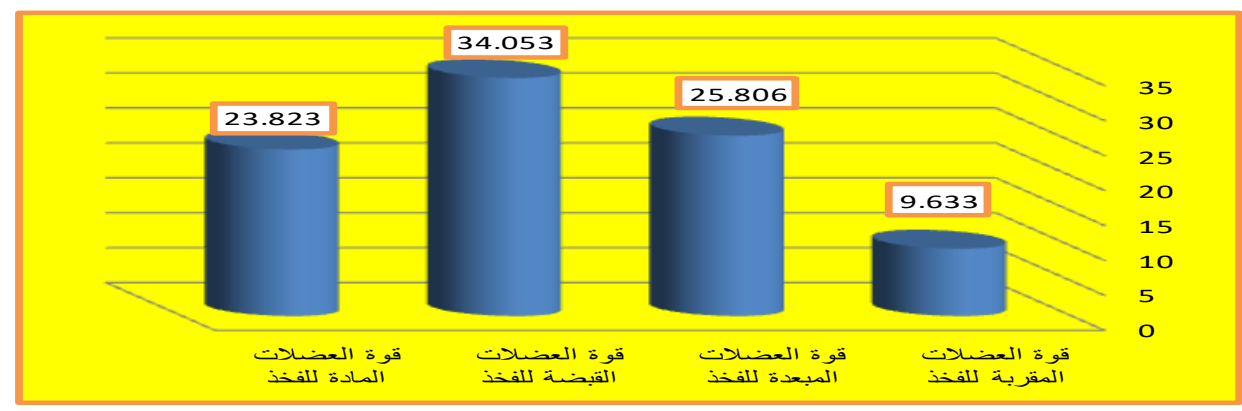

شكل رقم ( 11) يوضح قيمة حجم التأثير لقياسات القوة العضلية لمفصل الفخذ على الرجل الجهة العكسية للجراحة

جلول ( 27 ) المتوسط الحسابى والانحراف المعيارى للقياسات المتكررة (القبلى ، البينى الاول ،

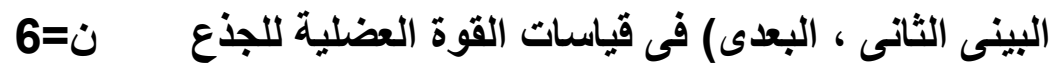

\begin{tabular}{|c|c|c|c|c|c|c|c|c|}
\hline \multicolumn{2}{|c|}{ القياس البعدى } & \multicolumn{2}{|c|}{ بعد المرحلة الثانية } & \multicolumn{2}{|c|}{ بعد المرحلة الأولى } & \multicolumn{2}{|c|}{ القياس القبلى } & \multirow{2}{*}{ القياسات } \\
\hline$\varepsilon \pm$ & س- & $\varepsilon \pm$ & س- & $\varepsilon \pm$ & س- & $\varepsilon \pm$ & س- & \\
\hline 2.366 & 43.00 & 3.082 & 32.50 & 1.095 & 19.00 & 1.169 & 2.17 & قوة العضلات القابضه \\
\hline 6.616 & 51.17 & 3.312 & 36.17 & 2.229 & 23.17 & 2.000 & 2.00 & قوة العضلات الباسطه \\
\hline
\end{tabular}

يتضح من الجدول رقم ( 27 ) و الخاص بالمتوسط الحسابى والانحر اف المعيارى وجود فروق معنويه فى القياسات المتكررة (القبلى ، البينى ، البعدى) لعينة البحث فى قياسات القوة العضلية للجذع.

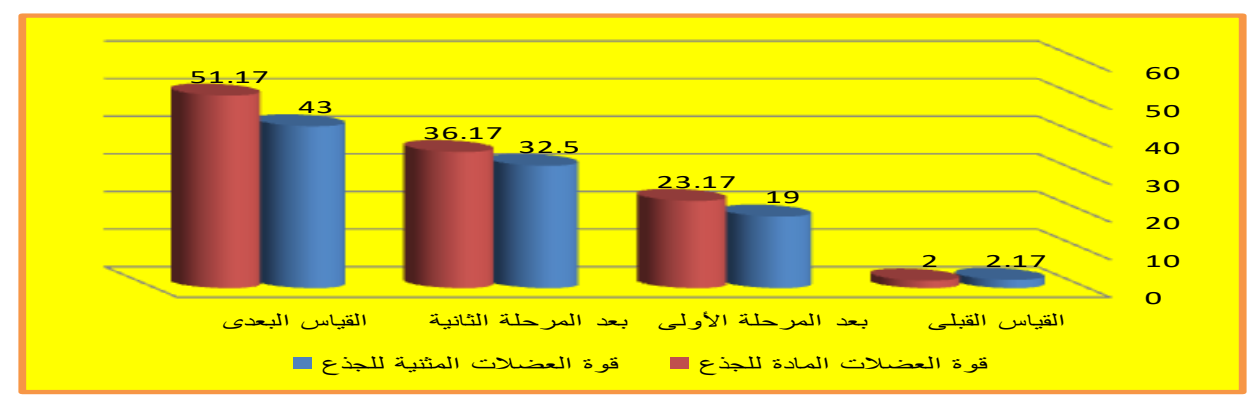

شكل رقم ( 12 ) يوضح المتوسط الحسابي للقياسات المتكررة (القبلى ، البينى الاول ، البينى الثانى ،

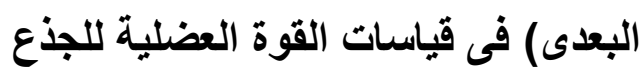


جدول ( 31 ) المتوسط الحسابى والاتحراف المعيارى ونسبة التحسن وقيمة " ت " المحسوية بين

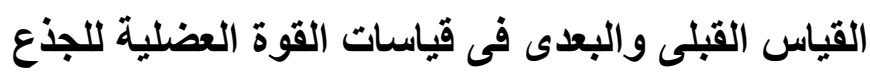

\begin{tabular}{|c|c|c|c|c|c|c|c|c|c|}
\hline \multicolumn{2}{|c|}{ التأثير } & \multirow{2}{*}{ " ق ت " " } & \multirow{2}{*}{$\begin{array}{c}\text { نسبة } \\
\text { \% }\end{array}$} & \multirow[b]{2}{*}{ المتوسطين } & \multicolumn{2}{|c|}{ القياس البعدى } & \multicolumn{2}{|c|}{ القياس القبلى } & \multirow[b]{2}{*}{ القياسات } \\
\hline مقار & قلتيمة & & & & $\varepsilon \pm$ & س- & $\varepsilon \pm$ & س- & \\
\hline مرتفع & 21.279 & $* * 41.65$ & 1881.56 & 40.83 & 2.366 & 43.00 & 1.169 & 2.17 & قالقابضه العضلات \\
\hline مرتفع & 10.126 & $* * 17.28$ & 2458.50 & 49.17 & 6.616 & 51.17 & 2.000 & 2.00 & قالباسطة للجذلات \\
\hline
\end{tabular}

"معنوية " ت " الجدولية عثد مستوى 0.05 = 2.571 ، عند مستوى 0.01 = 2.01

يتضح من الجدول رقم ( 31 ) وجود فروق ذات دلالة معنويـة فى قيمـة " ت " المحسوبة بين

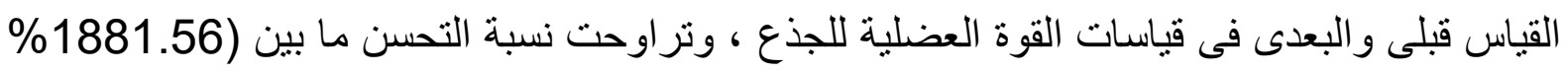

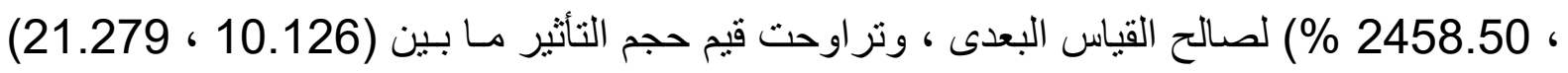

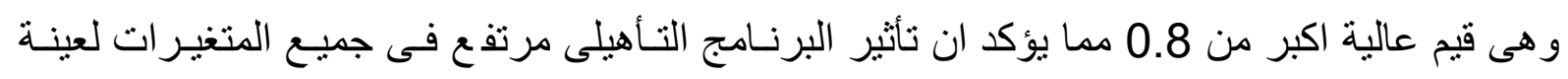

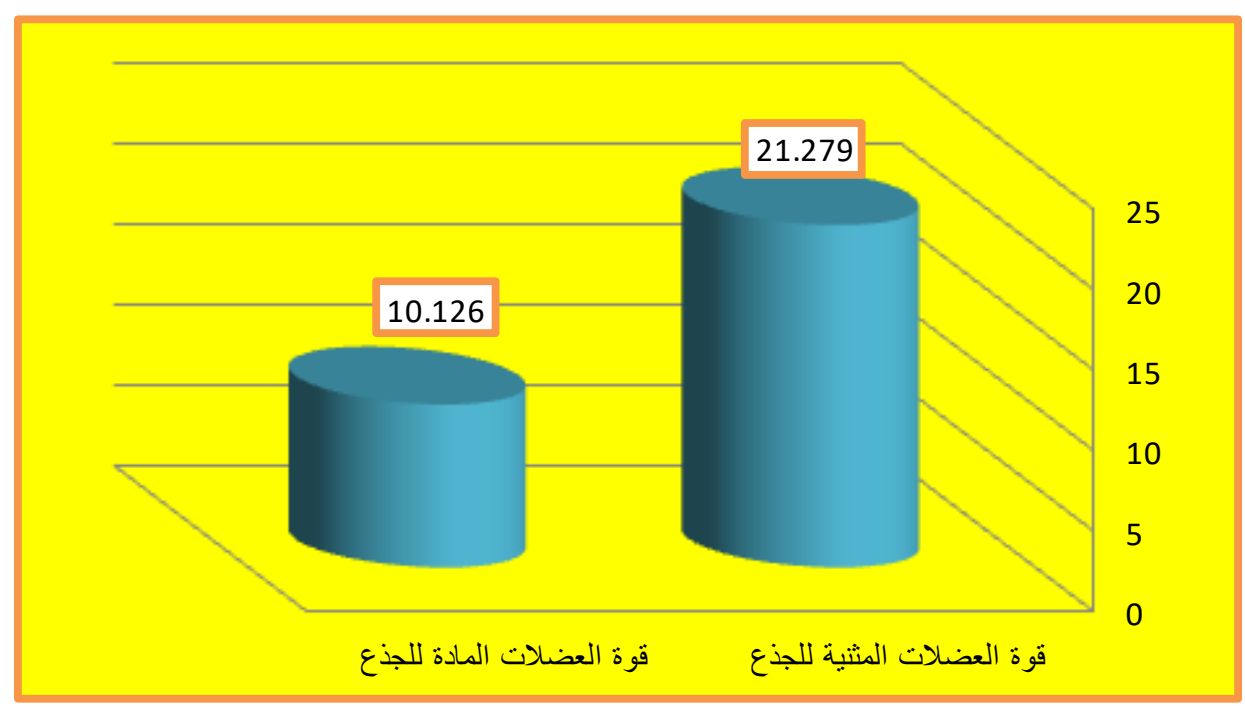

شكل رقم ( 18 ) يوضح قيمة حجم التأثير لقياسات القوة العضلية للجذع 
عرض نتائج مقياس درجة الإلم لعينة الدراسة :

جدول ( 32 ) المتوسط الحسابى والانحراف المعيارى للقياسات المتكررة (القبلى ، البينى الاول ،

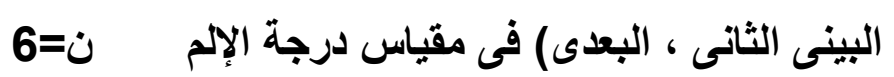

\begin{tabular}{|c|c|c|c|c|c|c|c|c|}
\hline \multicolumn{2}{|c|}{ القياس البعدى } & \multicolumn{2}{|c|}{ القياس البينى الثانى } & \multicolumn{2}{|c|}{ القياس البينى الاول } & \multicolumn{2}{|c|}{ القياس القبلى } & \multirow[t]{2}{*}{ القياسات } \\
\hline$\varepsilon \pm$ & س- & $\varepsilon \pm$ & س- & $\varepsilon \pm$ & س- & $\varepsilon \pm$ & س- & \\
\hline 0.606 & 0.33 & 0.894 & 2.50 & 0.917 & 5.92 & 0.753 & 8.83 & درجة الالالم \\
\hline
\end{tabular}

يتضح من الجدول رقم ( 32 ) و الخاص بالمتوسط الحسابى و الانحر اف المعيارى وجود فروق

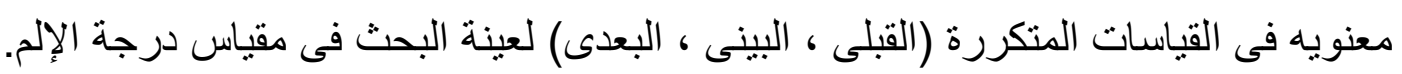

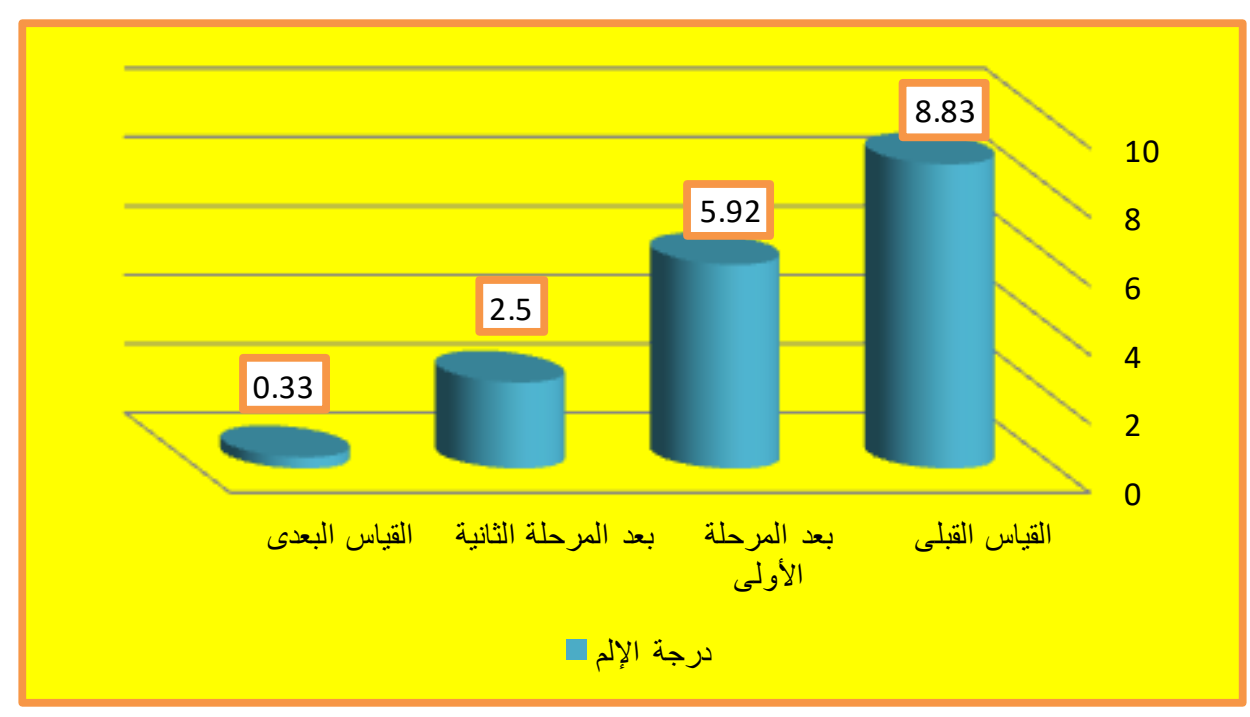

شكل رقم ( 11 ) يوضح المتوسط الحسابي للقياسات المتكررة (القبلى ، البينى الاول ، البينى الثانى ،

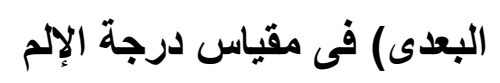

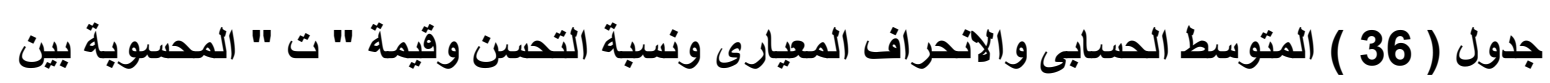
القياس القبلى والبعدى فى مقياس درجة الإلم الميلم

\begin{tabular}{|c|c|c|c|c|c|c|c|c|c|}
\hline \multicolumn{2}{|c|}{ التأتيّير } & \multirow[b]{2}{*}{ " قل " " قيمة } & \multirow[b]{2}{*}{$\begin{array}{c}\text { التحسن } \\
\text { \% }\end{array}$} & \multirow[b]{2}{*}{ المتوسطين } & \multicolumn{2}{|c|}{ القياس البعدى } & \multicolumn{2}{|c|}{ القياس القبلى } & \multirow[b]{2}{*}{ القياسات } \\
\hline مقدار & قاتيمة & & & & $\varepsilon \pm$ & 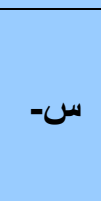 & $\varepsilon \pm$ & س- - & \\
\hline مرتفع & 12.357 & **26.88 & 96.26- & $8.50-$ & 0.606 & 0.33 & 0.753 & 8.83 & مقياس درجة الإلم \\
\hline
\end{tabular}


يتضح من الجدول رقم ( 36 ) وجود فروق ذات دلالة معنويـة فى قيمـة " ت " المحسوبة بين

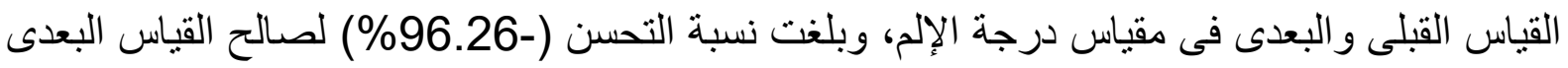

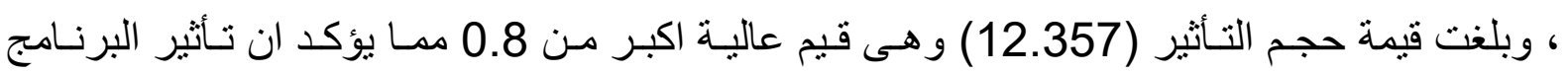
التأهيلى مرتفع فى جميع المتغير ات لعينة البحث.

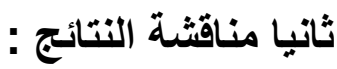

من خلال عرض النتائج التى تم التوصل إليها من القياسات (القبلى ـ اليينى الاول ـ البينى

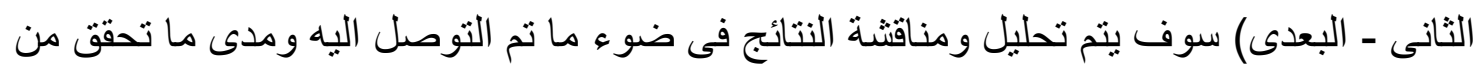

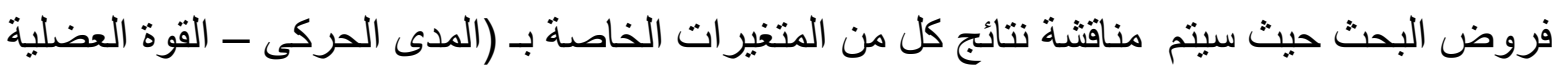

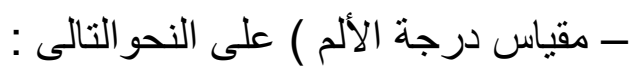

اولا : مناقثة نتائج الفرض الأول : يعمل البرنامج التأهيلى المقترح على تحسين المدى

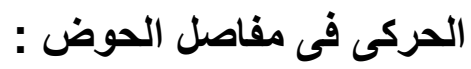

يتضح من الجدول رقم ( 6 ) ، و الجدول رقم ( 19 ) وجود فروق ذات دلالة معنوية فى قيمة " ت " المحسوبة للقياس القبلى و البعدى فى قياسات المدى الحركى لمفصل الفخذ على الرجل جهة الجراحة والجهة العكسية للجراحة بالترتيب حيث نراوحت نسبة التحسن ما بين (92.52\% ،

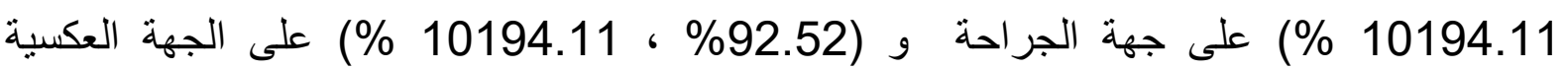
للجراحة ولصالح القياس البعدى ويعزى الباحث نسب التحسن الكبيرة فى النتائج بعد انتهاء البرنامج انه عقب العطليات الجر احيه يحدث إرتثاحات دموية مكان الجراحة تسبب التصاقات فى الانسجة والطبقات الداخلية فى موضع الجر احة وأيضا يحدث لين و إنحلال فى العضلات حول منطقة الجر احة نتيجة قلة

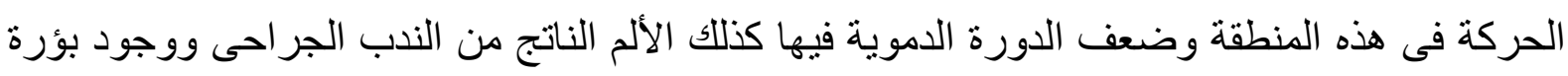

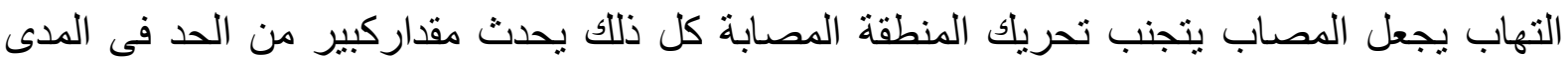
الحركى فى الدفاصل القريبه من مكان الجراحة لذلك بعد الثفاء و إنحسار الاعر اض السابقة تظهر نسب

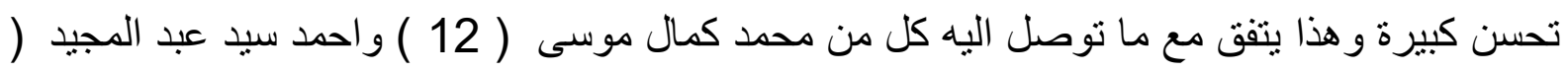

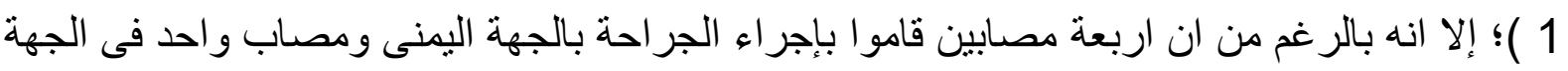
اليسرى ومصاب واحد فى كلا الجانبين إلا ان نتائج قياس المدى الحركى تؤكد التأثر الثنديد فى الجهة الاخرى حيث تقاربت القياسات القبليه فى الجهتين فى المدى الحركى ويعزى الباحث ذللك الى قرب الرجل العكسية للجراحة من مكان الجراحة ،ايضا الحوض ومفصل الارتفاق العانى هو نقطه اتصال مشتركه بين كلا الرجلين ومكان الجراحة ويتضح هذا التأثثر بصورة كبيرة في فياسات تبعيد مفصل 
الفخذ ، ايضا انقباض عضلة البطن المستقيمة كعضلة مساعدة اثناء تحريك كلا الرجلين يحدث الم مكان

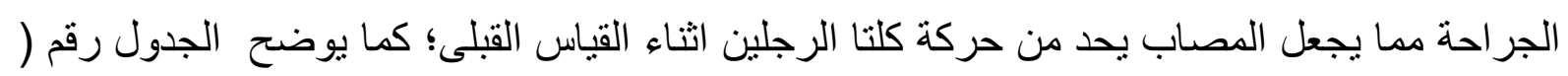
12 ) و الجدول رقم ( 17 ) وجود فروق ذات دلالة معنوية فى قيمة " LSD " للقياسات المتكررة

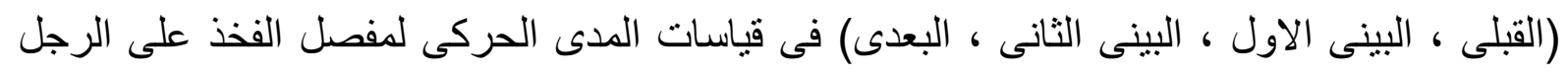

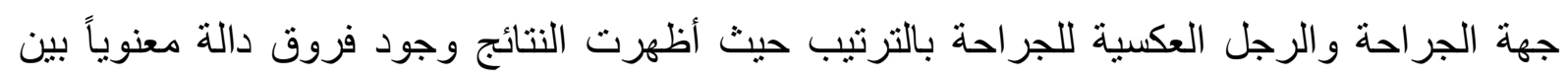
القياس البعدى وكلاً من (القياس البينى الثانى ـ القياس البينى الاول ـ القياس القبلى) ولصالح القياس القياس

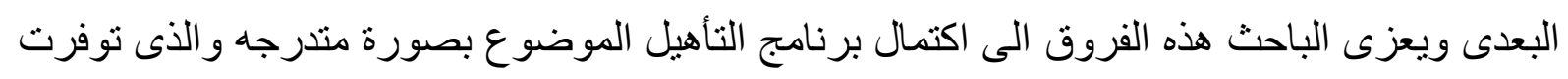

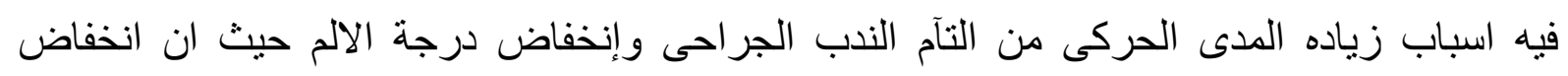
الثعور بالالم يتيح للاعب عمل إطالة اكبر للعضلات اثناء القياس واثناء التدريب في الثياء البرنامج

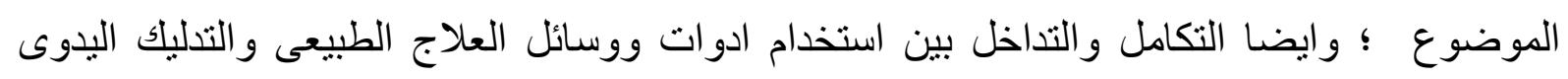

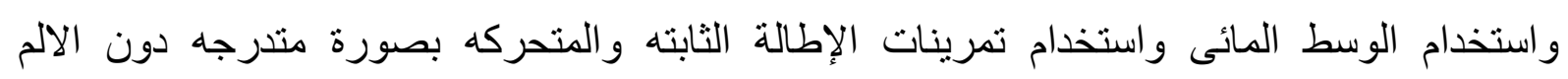

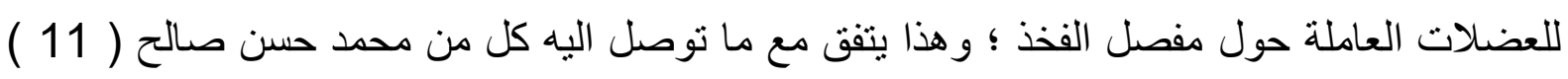

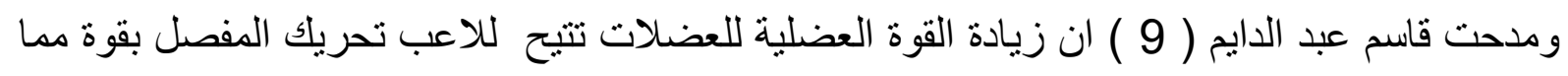
يؤدى الى تسجيل قياس اكبر والوصول الى اقصى مدى حركى ممكن كما يوجد فروق بين القياس

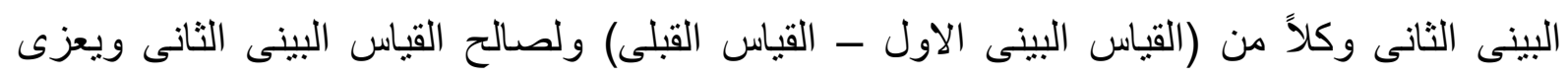
الباحث تحسن القياس البينى الثانى عن القياس البينى الاول الى بدء استخدام الوسط المائى فى التأهيل

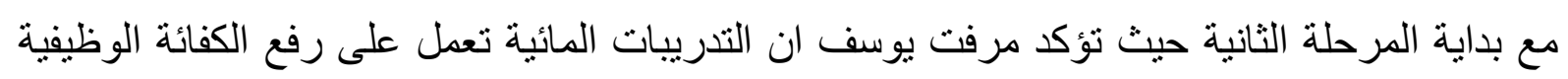

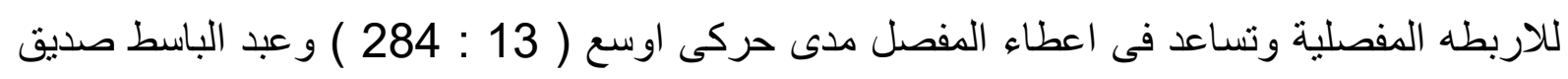

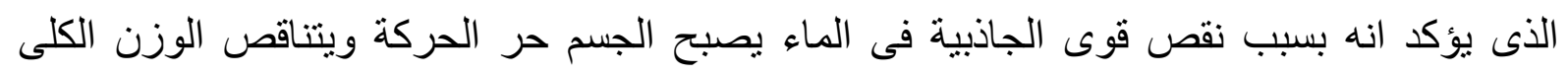

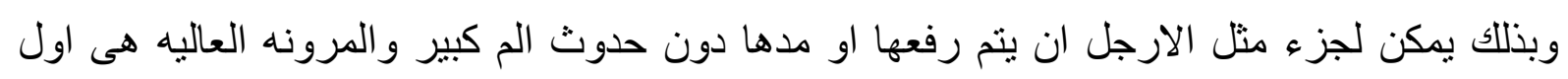

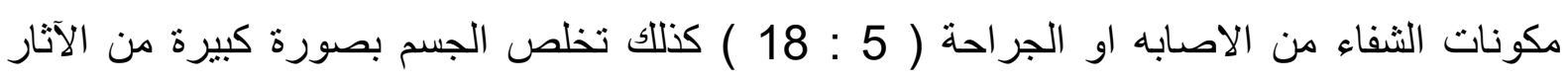

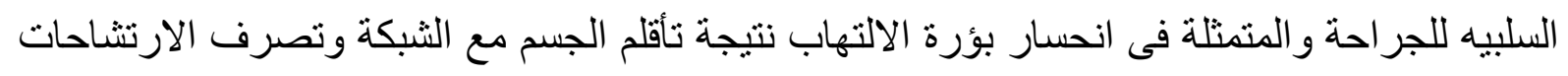

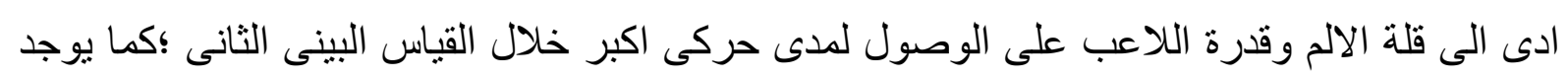

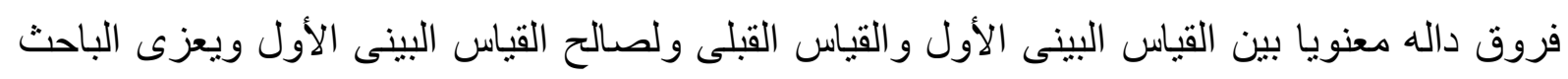

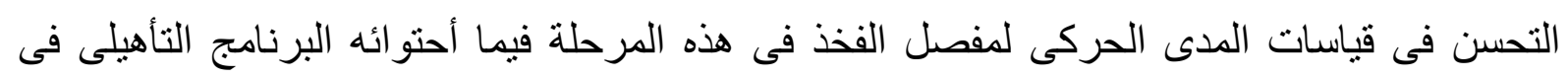

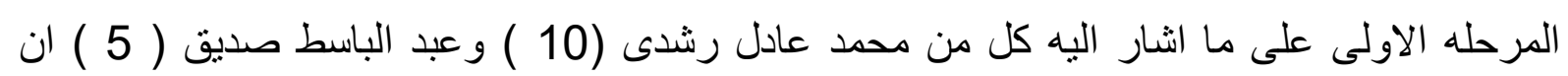

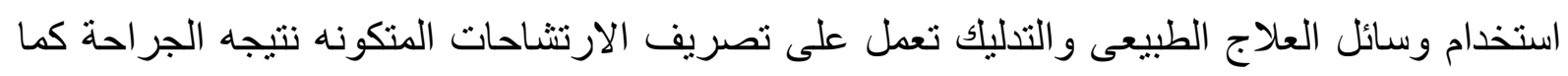

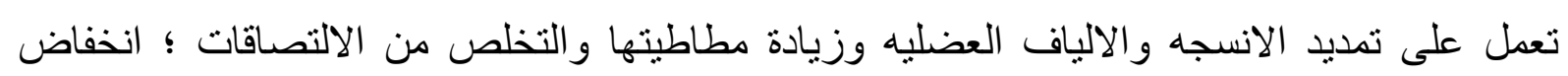
درجة الثعور بالالم نتيجة التآم الندب الجراحى والطبقات الخارجية للبطن يتيح للاعب تحريك الرجل 
الى مدى حركى اكبر فى القياسات المختارة ؛ كما ان استخدام تمرينات المرونة الثابتة لحدود الالم

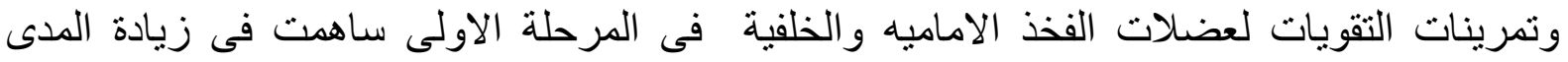

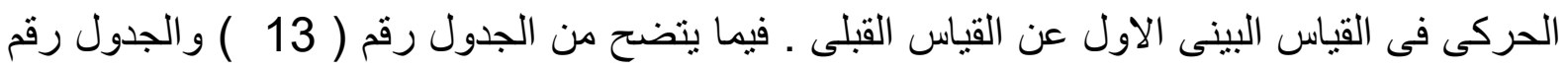
( 18 ) نسب التحسن بين القياسات المتكررة (القبلى ، البينى الاول ، البينى الثانى ، البعدى) فى قياسات

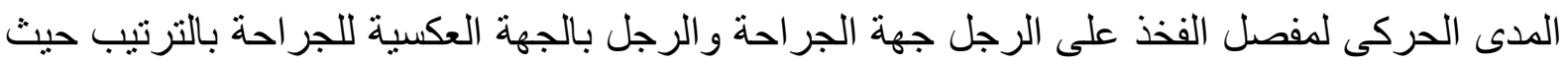
جاءت نسبة التحسن بين القياسات لصالح القياس البعدى ثم القياس البينى الثانى ثم القياس البينى الاول

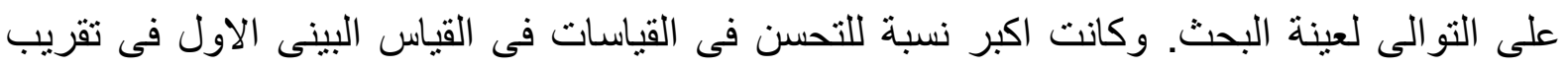

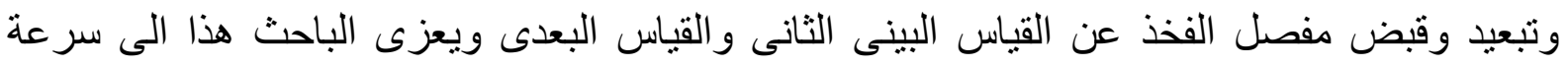

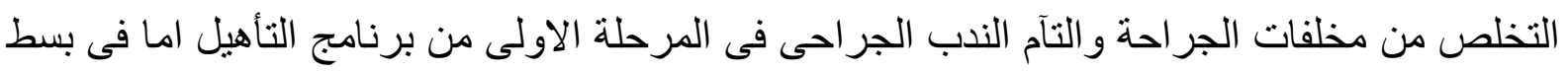
مفصل الفذذ فكان اكبر نسبه للتحسن فى القياس فكانت فى القياس البينى الثانى وذللك لعدم اجر اء قياس قبلى فى بسط مفصل الفخذ حيث يتطلب ذللك شد واسنطالة فى مكان الجراحة وهو ما حذر منه الاطباء

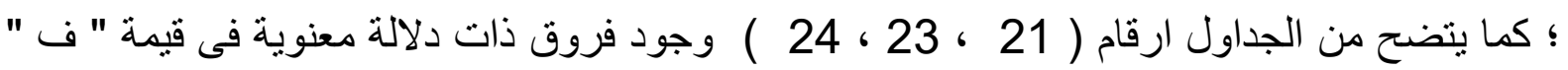
المحسوبة للقياسات المتكررة (القبلى ، البينى الاول ، البينى الثانى ، البعدى) فى قياسات الددى الحركى

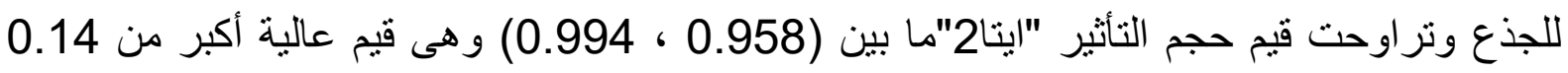

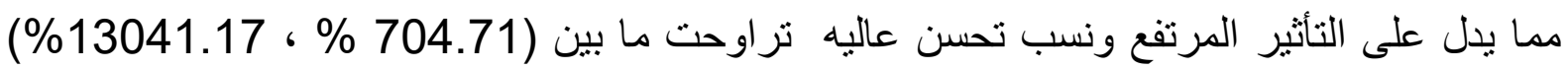

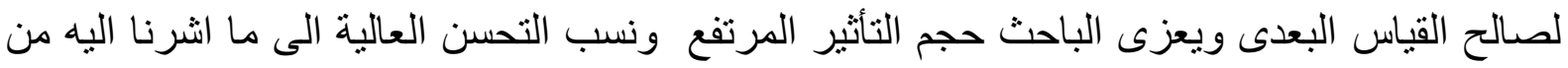

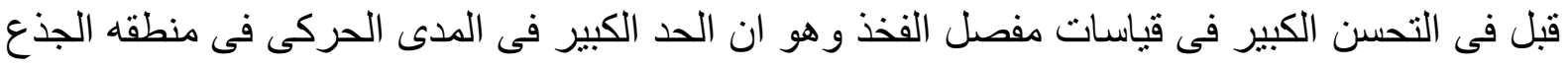
فى القياس القبلى بعد الجراحة مباشرة نتيجه الندب الجراحى وبؤرة الالتهاب ؛ وضعيات قياس المدى الحركى لقبض الجذع ينطلب ثنى البطن مما يسبب انضغاط للجرح اما قياس المدى الحركى لمد البطن يحدث شد واستطالة للجرح وكل ذللك يسبب الم شديد ويضر بالجراحة؛|يضا وجود نجمعات دموية

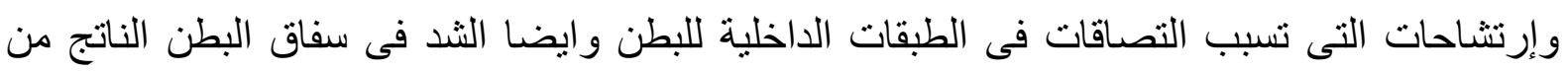
تركيب الثبكة والالم الذى يصاحب الحركه كل ذلك يؤثر على القياس القبلى بصورة كبيرة ويعطى حجم

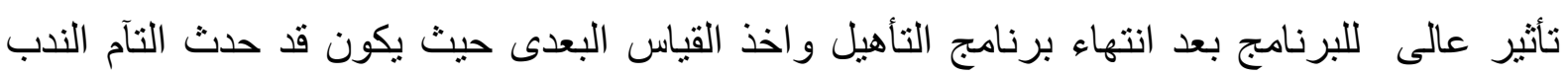

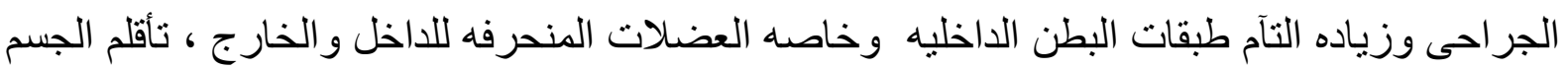
مع الثبكة الجراحية ، انخفاض درجة الالم ؛اما التحسن الكبير فى المدى الحركى فى القياس البينى

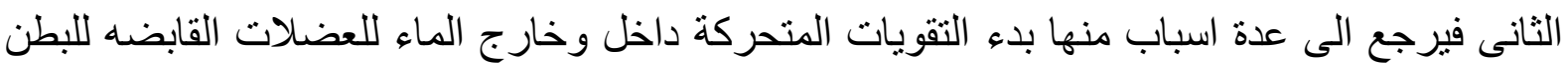

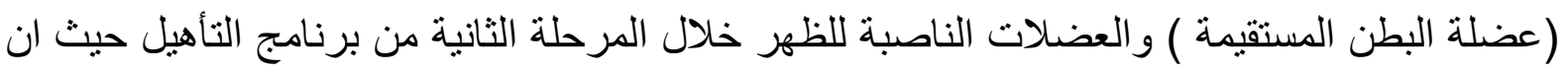

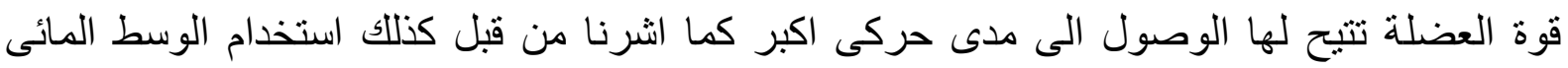
حيث يساعد الوسط المائى على اكساب المرونه الطبيعيه كما تثبر مرفت يوسف ان العضلات يمكنها 
التحرك بسهولة وبدون الم فى الماء كما ان التدفئة فى الحمام العلاجى تساعد على استرخاء العضلات . و الطفو ذو اهميه كبرى فى تدريب الماء حيث ان العديد من الحركات يمكن اداؤها غالبا بدون الم ( 13

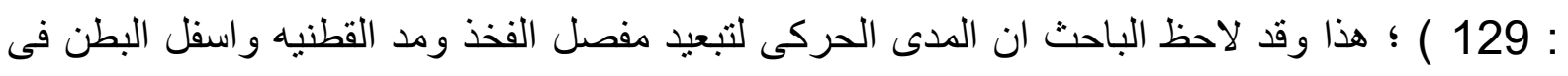
لاعبى كرة القدم المصابين بالفتق الرياضى تزيد فى القياس عن كثير من اقرانهم الغير مصابون

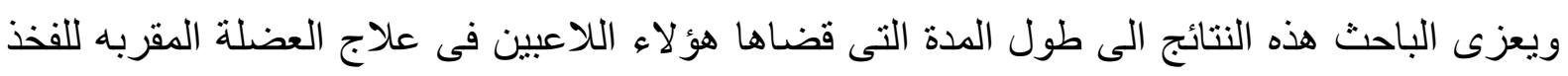

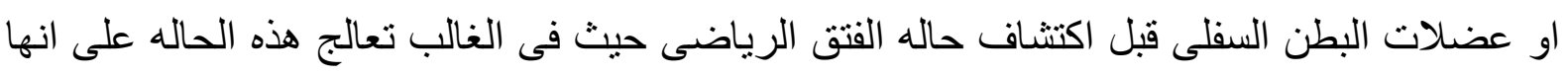

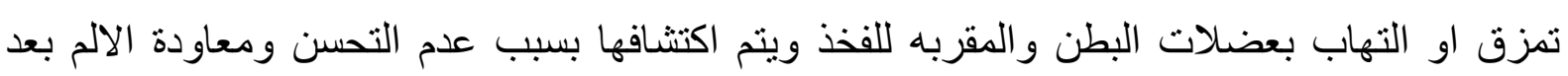
محاولة اللاعب الرجوع الى التدريب مع الفريق.

ثانياً : مناقثة نتائج الفرض الثانى : يؤثر البرنامج التأهيلى المقترح إيجابيا على قوة عضلات

البطن و العضلات العاملة على مفصل الفخذ :

يتضح من الجداول ارقام ( 26 ) ، ( 30 ) ، وجود فروق ذات دلالة معنوية فى قيمة " ف " المحسوبة للقياسات المتكررة (القبلى ، البينى الاول ، البينى الثانى ، البعدى) فى قياسات القوة العضلية لمفصل

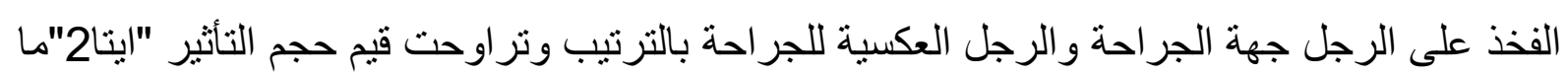

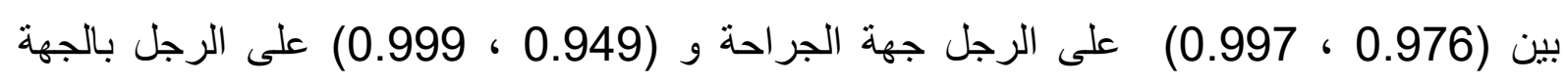

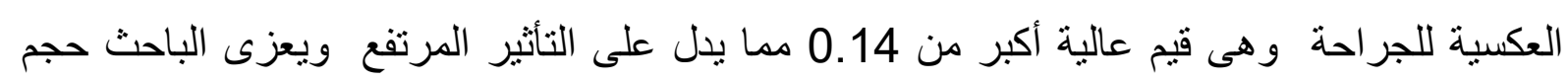

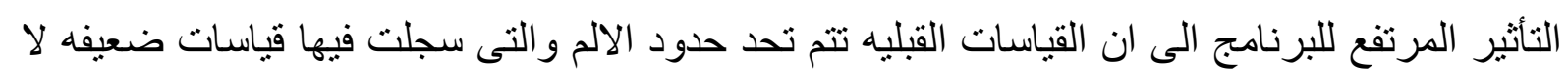

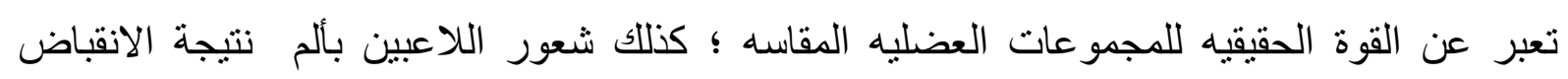

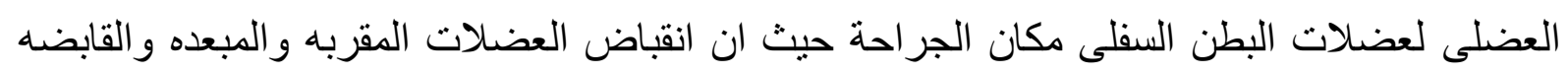
و الباسطه للفخذ عند انقباضها تنقبض معها عضلات البطن كعضلات مساعده ؛ بعض الاوضاع التهان التى يتم قياس القوة العضليه منها قد تتعارض مع تعليمات الجراحين على سبيل المثال عند قياس قوة العضلات

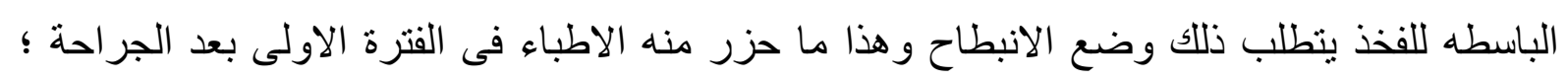

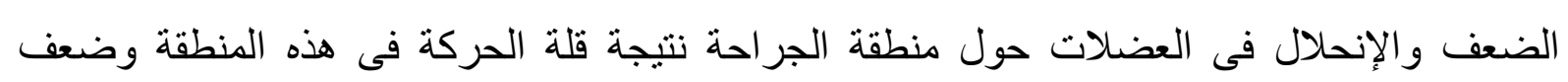

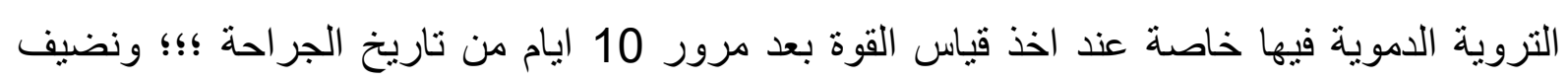
على كل ذلك خوف اللاعب من عمل انقباض عضلى نتيجه لتحذير الجراحين من الانقباض القوى

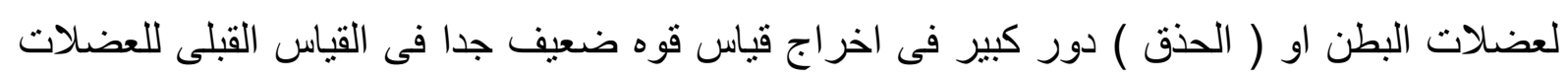

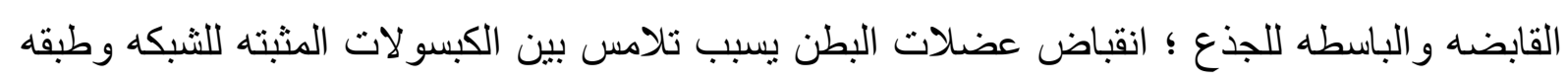

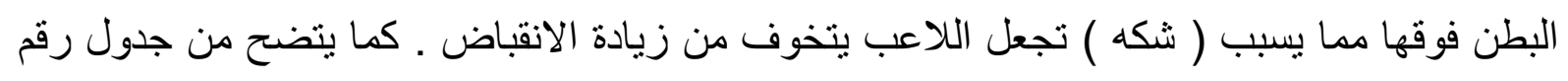

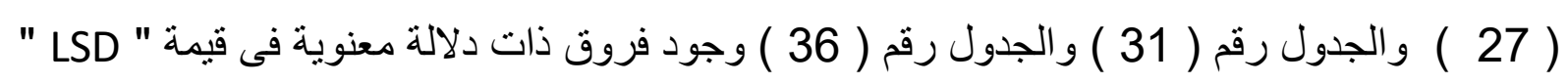


للقياسات المتكررة (القبلى ، البينى الاول ، البينى الثنانى ، البعدى) فى قياسات القوة العضلية لمفصل الفخذ على الرجل جهة الجراحة والرجل بالجهة العكسية للجراحة وعضلات الجذع بالترتيب حيث

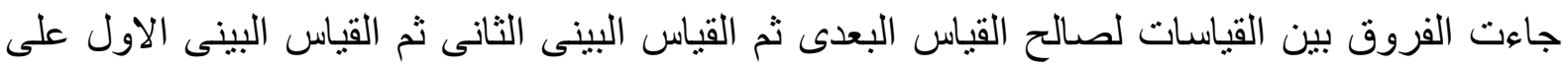
التوالى لعينة البحث حيث يوجد فروق بين القياس البعدى وكلا من ( القياس البينى الثانى ـ القياس البينى الاول - القياس القبلى ) ولصالح القياس البعدى ويعزى الباحث هذا الى بدء استخدام تمرينات

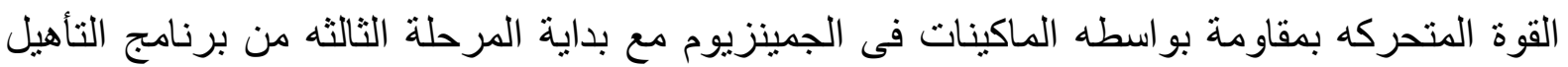
حيث ساهت فى رفع القوة العضليه كذللك ساهت تمرينات التحمل العضلى وتمرينات التحمل الدورى فى زيادة امداد العضلات بالدم الاكسوجينى مما يساعد على زيادة حجم الالياف العضليه و الذى يتناسب طرديا مع القوة العضلية وهذا يتفق مع ما توصل اليه كل محمد كمال موسى وعبد الحليم كامل

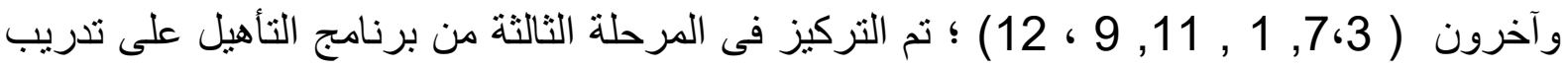
المجموعات العضليه وهو ما اكد عليه كل من تيودور بومبا وميشيل كاريرا 2005حيث اكدوا على 6 قو انين لتدريب وتنمية القوة القانون الثانى منها (تدريب العضلات كمموعات عضليه وليس تدريبا فرديا ) ،كنللك إنخفاض درجة الالم حيث ان انخفاض الثعور بالإلم يتيح للاعب اخر اج انقباض عضلى لهابل ثابت اكبر للعضلات اثناء القياس و اثثاء التدريب فى البرنامج الموضوع لان القياس يكون لحدود درجة

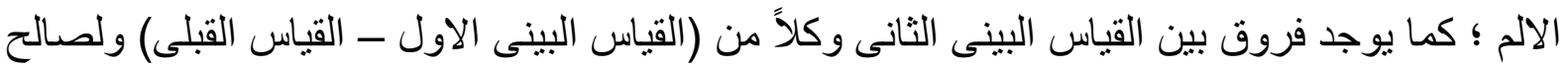
القياس البينى الثانى ويعزى الباحث هذا الى استخدام الوسط المائى فى التأهيل فى المرحله الثانيه من برنامج التأهيل حيث تؤكد مرفت يوسف الى ان التدريب المعتدل تحت الماء للإصابات الرياضية

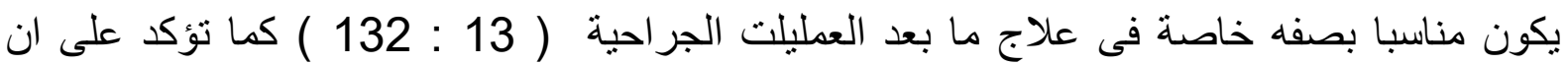
الضغط الو اقع على مساحة الاجزاء المغمورة من الجسم يعد اسلوب تأهيل لتقويه العضلات ( 13 : 13 : 282 ) ايضا استخدام تمرينات القوه الثابته و المتحركه كان له دور فى زيادة القوة العضليه فى المرحلة الثانيه من برنامج التأهيل ، بدء تدريب العضلات القابضه و الباسطه للفخذ والجذع و العضلات المقربه و المبعدة بمقاومة باستخدام الاستكا المطاطى مع بداية المرحلة الثانية من برنامج التأهيل ادى الى التطور السريع فى هذه المرحلة فى قياسات القوة ، زيادة الددى الحركى وقرب الوصول الى المعدلات الطبيعيه

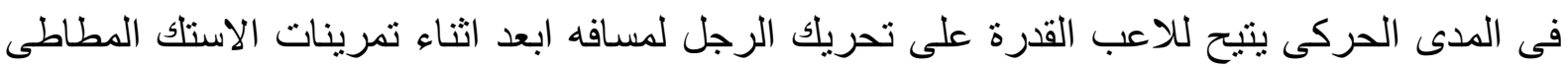
فتزيد المقاومه مما يؤثر فى زيادة القوة العضلية ؛ كما يوجد فروق بين القياس البينى الأول والقياس القبلى ولصالح القياس البينى الأول ويعزى الباحث هذا الفرق الى انخفاض درجة الالم مما يتيح للاعب

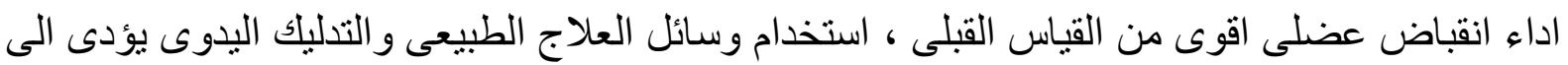
نشاط الدورة الدمويه فى العضلات التى يتم تدليكها ويزيد من الدم الاكسوجينى فى هذه العضلات مما لنا

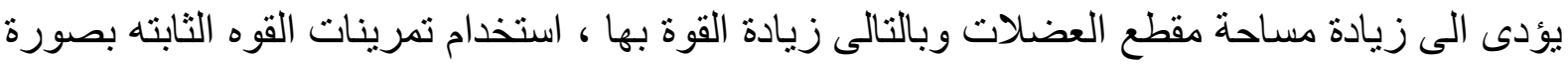


متدرجه مع بدايه الاسبوع الثالث للبرنامج ساعد على سرعة استعادة المصابين للقوه العضلية ،ايضا استخدام التنبيه الكهربى على العضلات المقربه والمبعدة والقابضه والباسطه للفخذ والقابضه و المادة

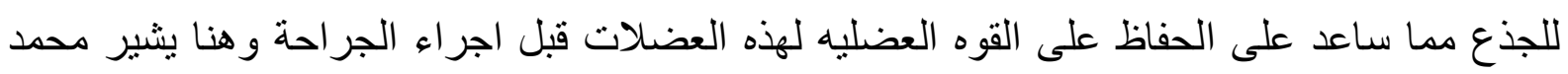
عادل رشدى الى مصطلح ( muscle stimulation) حيث يؤكد على ان استخدام التتبيه الكهربى

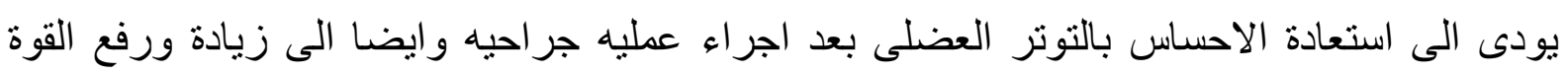

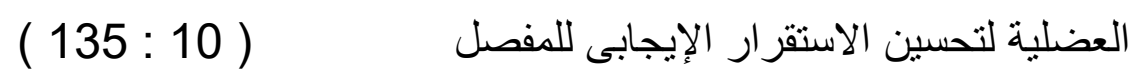

ثالثاً : مناقشة نتائج الفرض الثالث : يحد البرنامج التأهيلى المقترح من درجه الالم الذى يتعرض له

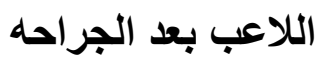

يتضح من جدول رقم ( 33 ) وجود فروق ذات دلالة معنوية فى قيمة " ف " المحسوبة للقياسات

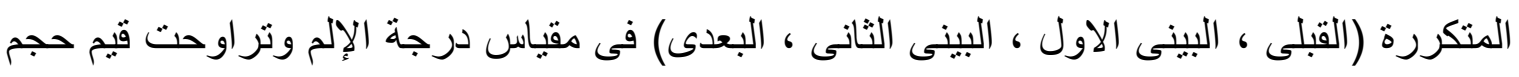

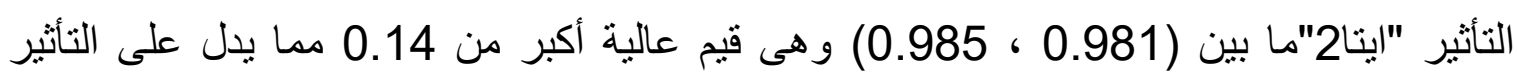

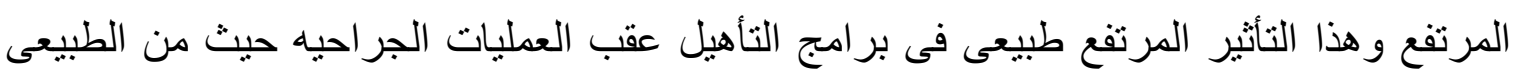

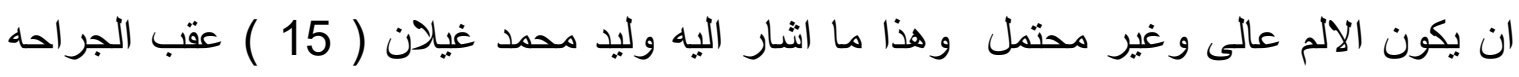

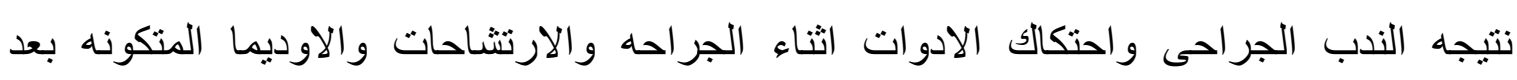

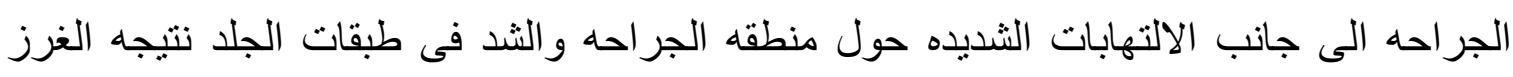
الجراحيه والتى مع مرور الوقت تقل حدة هذه الاثار فتتخفض درجه الالم ويظهر معدل التأثنير

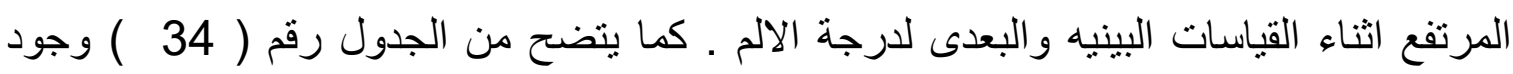

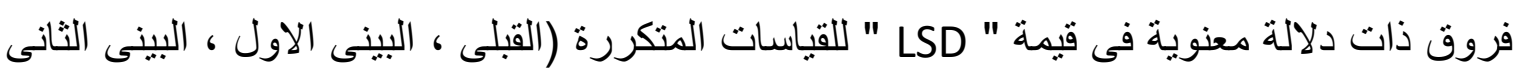

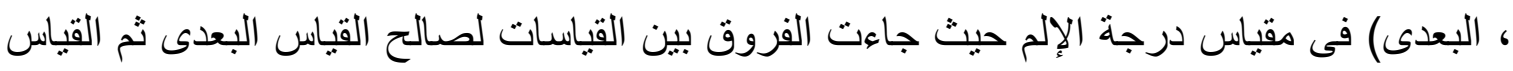

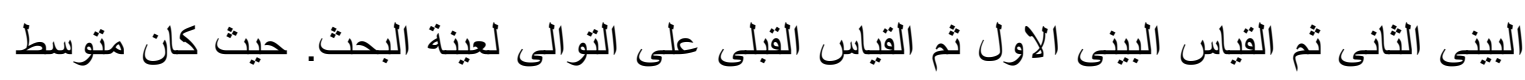

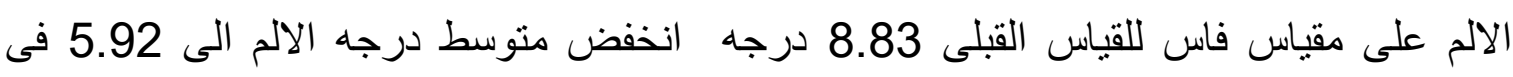
القياس البينى الاول ويعزى الباحث هذا الانخفاض الى التآم الندب الجراحى وقد ساعد على سلى سرعة الته التآم الندب الجراحى استخدام الليزر العلاجى وموجات الالترا سونك التى نؤدى الى زئى زيادة نفاذية

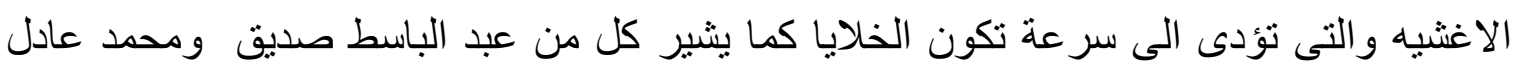

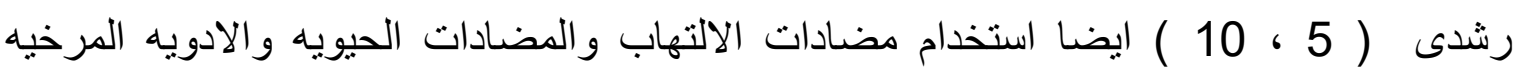
للعضلات عقب الجر احة ساهم فى انخفاض درجة الالم فى هذه المرحله وانخفض متوسط درجها

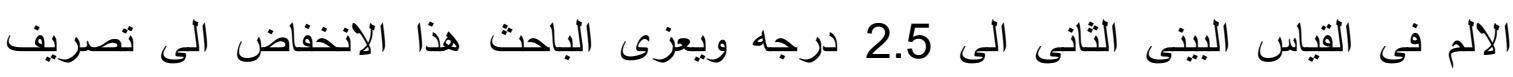

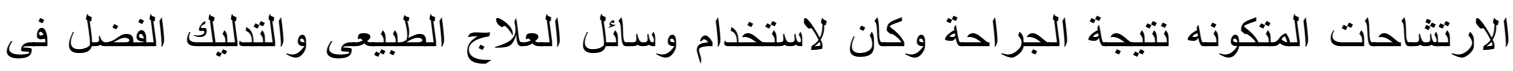


تسريع عمليه التخلص من مخلفات الجراحة كما يشير كل من عبد الباسط صديق و اسامه رياض

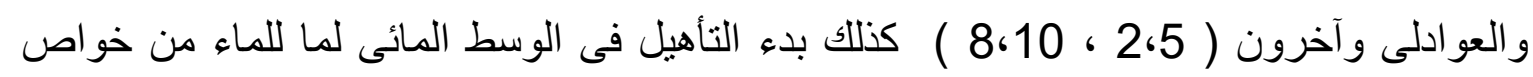

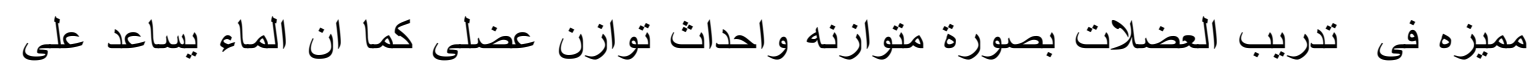
استرخاء العضلات ( 2 ، 5 ،13 ) وصول الددى الحركى الى مستوى يقارب الطبيعى أدى الى

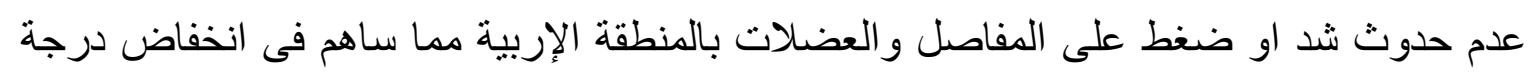

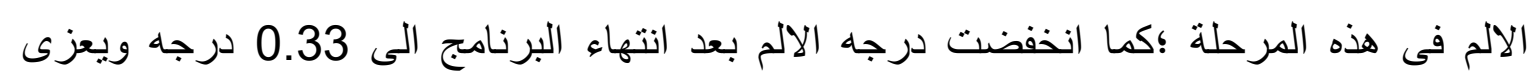

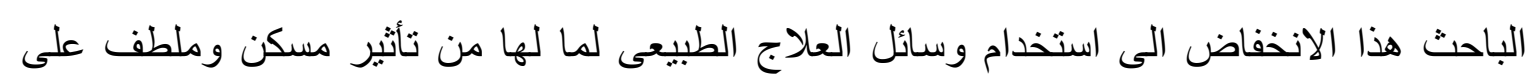

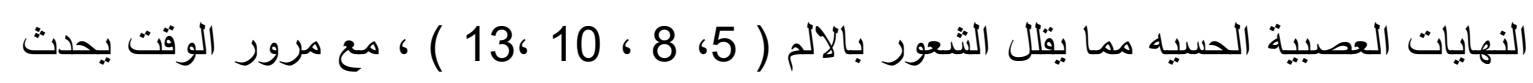

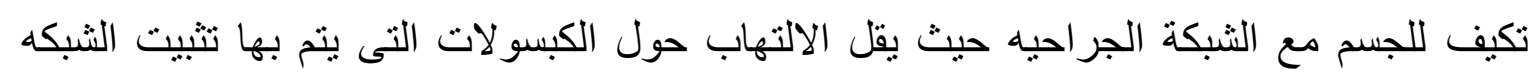
الجر احيه والتآم طبقات اكثر من الطبقات الداخليه لجدار البطن ، التدرج فى التأهيل وزيادة القوة

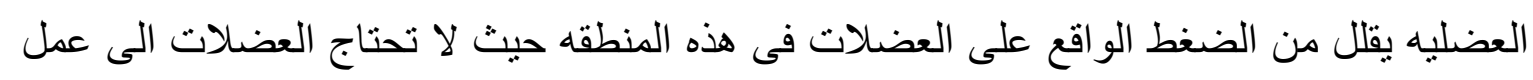

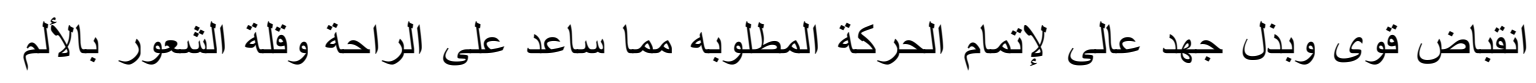

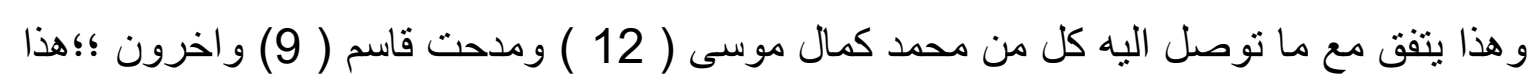

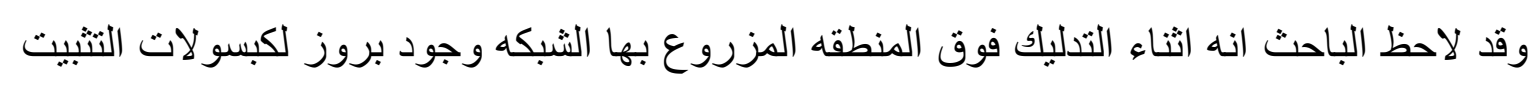

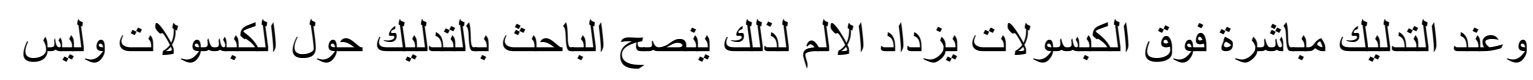

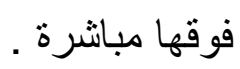

الأستنتاجات :

1- كان للبرنامج تأثير ات متباينه على عودة الطرف المصاب لحالته الطبيعية

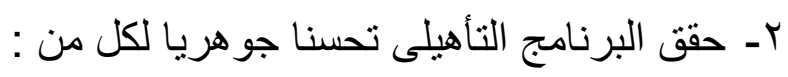
- زيادة المدى الحركى لمفصل الفخذ فى حركات التقريب و التبعيد و القبض و البسط . - زيادة المدى الحركى لمنطقة أسفل الظهر فى حركات الثنى و المد -زيادة القوة العضلية على العضلات العاملة على الحوض . ـ قله و إنخفاض الألم تدريجيا و اختفاءه فى 6 حالات - إختفاء الاثار السلبية للجر احة مثل التورم و التجمعات الدموية . 
3- كانت هنالك شكوى متكررة من وجود (تتميل ) مكان الجراحة بالمنظار وبرر الجراحون ذلك بإحتمال حدوث إنحباس داخل الندب الجر احى .

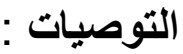

1- الاسترشاد بالبرنامج التأهيلى المقترح عند التأهيل بعد جراحة الفتق الأربى بالمنظار الجر احى . 2- ضرورة الأهتمام بالتثقف الصحى للمرضى وتعليمهم بما يجب إتباعه بعد الجراحة . 3- الأستمر ار فى ممارسة تمرينات المرحلة الثالثة عقب الأنتهاء من البرنامج . 4- ضرورة عمل مقارنه بين التأهيل بالجر احة التقليدية و الجر احة بالمنظار . مر اجع العربيه 1-احمد سيد عبد المجيد احمد ، برنامج تأهيلى لتحسين الاداء الوظيفى للمصابين بكابئ بكسر عظمة الفخذ ما

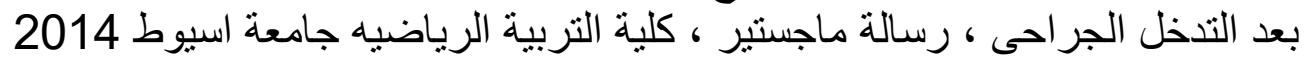
2- اسامه رياض عونى ،الطب الرياضى وإصابات الملاعب ، دار الفكر العربى القاهره 2002

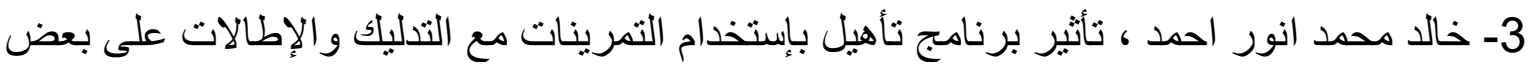
حالات تمزق عضلات البطن السفلى للاعبى كرة القدم ، رسالة ماجستير كلية التربية التربية الرياضية التياتية ،

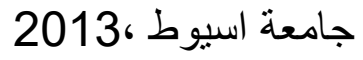

4- صفاء صفاء الدين الخربوطلى ، اللياقة القوامية و التدليك ، دار الجامعيين للطباعة و التجليد 2011 التئ

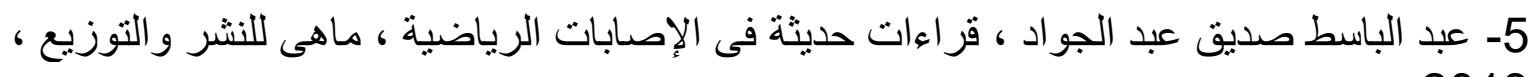
2013

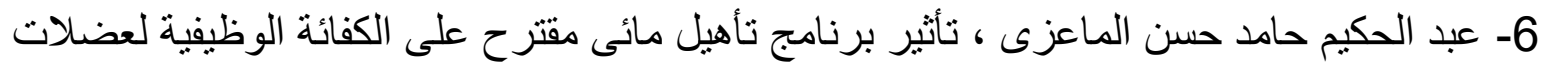

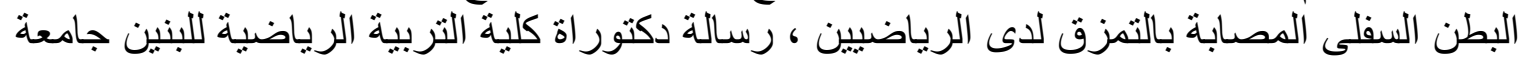

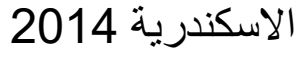

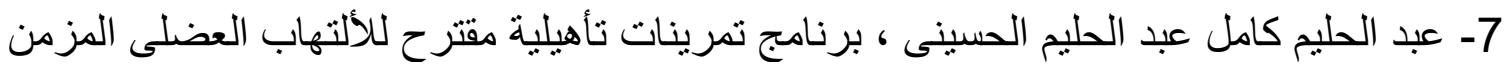

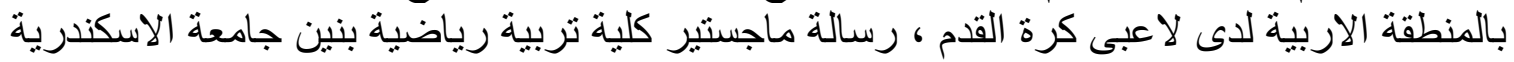
غير منشورة ، 2009

8- عبد العظيم العوادلى ، الجديد فى العلاج الطبيعى والإصابات الرياضيه ، دار الفكر العربى 1999

9- مدحت قاسم عبد الدايم ، فاعلية عنصرى القوة و المرونة فى الوقاية من الإصابات الثائعة وتأثير

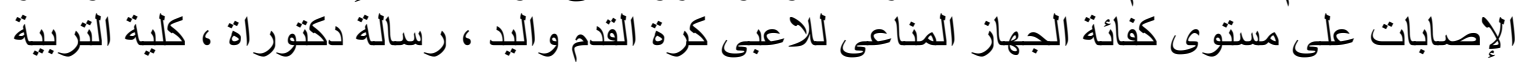

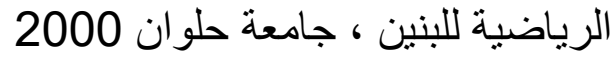

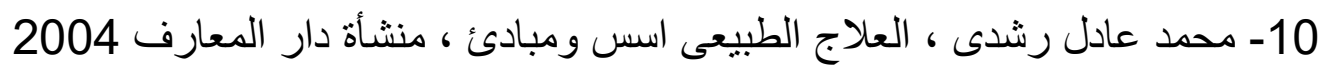

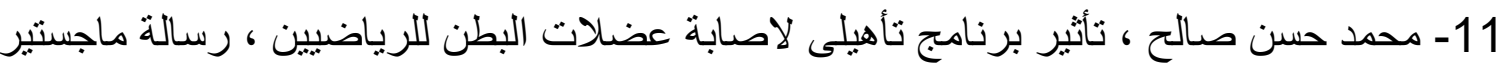
كلية تربية رياضية بنين جامعة الاسكندرية ، 2005 
12- محمد كمال على موسى ، التاهيل البذنى و الحركى لمفصل الفخذ بعد جر احة الاستبدال الكامل

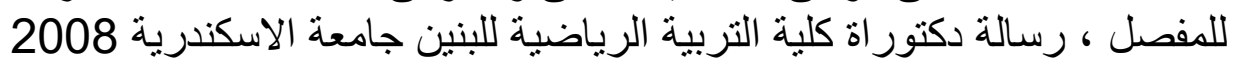

13- مرفت السيد يوسف ، مشكلات الطب الرياضى ، الثنهابى للطباعة ، الطبعة الثالثة ، 2012

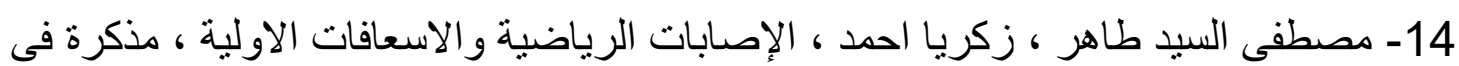
التأهيل الرياض ، مرحلة الماجستير ، 2014

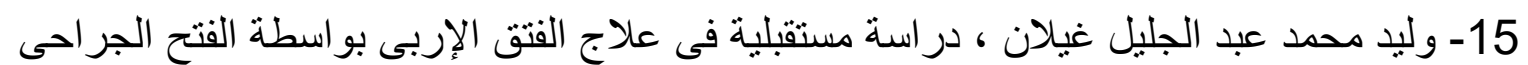

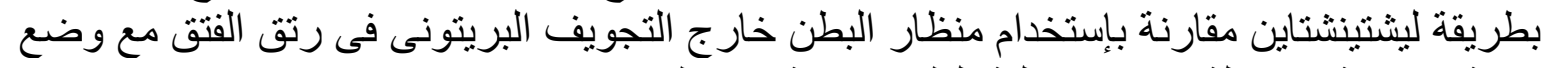
شبكة جر احية ، رسالة ماجستير كلية الطب جامعة اسيوط 2011

16 -BakiEkçi and TahsinBeyzadeoglu. Groin Pain in Athletes - Sports Hernia and Osteitis Pubis .Yeditepe University, Medical School, Department of General Surgery, Istanbul, Turkey 2009

17 -Joseph E. Chebli, M.D., Justin D. Rothmier, M.D., Kimberly Harmon, M.D. Sports Hernia: A Bilateral Disease

18 - Johnson JD, Briner WW: Primary care of the sports hernia: recognizing an often-overlooked cause of pain. The Physician and Sportsmedicine. Feb 2005.

19 - KIM EDWARD LeBLANC, MD, PhD; LEANNE L. LeBLANC, MD; and KARL A . Inguinal Hernias: Diagnosis and Management . Louisiana State University School of Medicine, New Orleans, Louisiana 2013

20 -Lepski G, Vahedi P, Tatagiba MS, Morgalla M. Combined Spinal Cord and Peripheral Nerve Field Stimulation for Persistent Post-Herniorrhaphy Pain. Neuromodulation. 2012

21 - Litwin DE, Sneider EB, McEnaney PM, Busconi BD. Athletic pubalgia (sports hernia). Clinics in sports medicine. 2011

22 - Nam A, Brody F. Management and therapy for sports hernia. Journal of the American College of Surgeons. 2008

23 - Neumayer L, Giobbie-Hurder A, Jonasson O, Fitzgibbons R, Dunlop D, Gibbs $J$, Reda A, Henderson W. Open mesh versus laparoscopic mesh repair of inguinal hernia. N Eng J Med. 2004

24 -Paul H Caudill, John A Nyland, Chad E Smith, Jonathan G Yerasimides and John Lach Sports Hernias: A Systematic Literature Review 2008 
ثالثا مو اقع شبكه المعلومات الدوليه

موقع الدكتور عبدالحميد المؤمن - جر احة اصلاح فتق البطن-25 www.dralmomen.com/page.aspx?PagelD=41 